\title{
Sovereign Debt Restructurings in Grenada: Causes, Processes, Outcomes, and Lessons Learned
}

\author{
Tamon Asonuma \\ International Monetary Fund, U.S.A. \\ tasonuma@imf.org \\ Mike Xin Li \\ International Monetary Fund, U.S.A. \\ xli3@imf.org \\ Saji Thomas \\ International Monetary Fund, U.S.A. \\ sthomas3@imf.org \\ Michael G. Papaioannou \\ International Monetary Fund, U.S.A. \\ michaelgpapaioannou@gmail.com \\ Eriko Togo ${ }^{1}$ \\ International Monetary Fund, U.S.A. \\ etogo@imf.org
}

\begin{abstract}
This paper documents the two debt restructurings that Grenada undertook in 2004-06 and 2013-15. Both restructurings emerged as a consequence of weak fiscal and debt situations, which became unsustainable soon after external shocks hit the island economy. The two restructurings provided liquidity relief, with the second one involving a principal haircut. However, the first restructuring was not able to secure long-term debt sustainability. Grenada's restructuring experience shows the importance of (1) establishing appropriate debt restructuring objectives; (2) committing to policy reforms and maintaining ownership of the restructuring goals; and (3) engaging closely and having clear communications with creditors.
\end{abstract}

JEL classification: F34, G15, H63

Key words: Sovereign Debt; Sovereign Defaults; Sovereign Debt Restructurings; Serial Debt Restructurings; Serial Defaults; Grenada; Disaster Clause

\footnotetext{
Asonuma: Strategy Policy and Review Department, International Monetary Fund, 700 19th Street, N.W. Washington, D.C. 20431 USA, tasonuma@imf.org. Li: Strategy Policy and Review Department, International Monetary Fund, 700 19th Street, N.W. Washington, D.C. 20431 USA, xli3@imf.org. Papaioannou (corresponding): Monetary and Capital Market Department, International Monetary Fund, 700 19th Street, N.W. Washington, D.C. 20431 USA, +1-202-527-0266, michaelgpapaioannou@gmail.com. Thomas: Fiscal and Affair Department, International Monetary Fund, 700 19th Street, N.W. Washington, D.C.20431 USA, sthomas3@imf.org. Togo: Strategy Policy and Review Department, International Monetary Fund, 700 19th Street, N.W. Washington, D.C. 20431 USA, etogo@imf.org.
} 


\section{INTRODUCTION}

Grenada experienced a second sovereign debt restructuring during 2013-15, about a decade after its first restructuring during 2004-06, which was triggered by Hurricane Ivan. This paper analyzes several issues pertinent to Grenada's two sovereign debt restructurings, such as the causes, the processes, and the outcomes. The paper focuses on three key aspects: (1) why did the country restructure its debt? What macroeconomic indicators signaled the vulnerability of policies that ultimately led to the debt restructurings?; (2) how did the debtor-creditor relationship develop? What were the modalities and length of negotiation and communication with private, official bilateral and multilateral creditors (including an IMF-supported program)? Are there any legal and operational characteristics that might have influenced the renegotiation process?; and (3) did the restructurings fully address debt sustainability concerns? What was the impact on the liquidity and solvency conditions after each restructuring? ${ }^{2}$ What is the creditor loss, along with the prospects for future market re-access?

Sovereign debt restructurings take place at times of acute financial and fiscal distress for the sovereign and usually involve a "haircut" in terms of a debt reduction in present value (PV) terms. Most restructurings occur after a default, but some are preemptive, that is, they are implemented without any missed payments (Asonuma and Trebesch, 2016). The main determinants of restructurings, as well as defaults, are over-indebtedness (debt-to-GDP ratio) and cash illiquidity, resulting in the government's inability to service the debt (rollover risks). Factors such as political instability and external shocks, in particular commodity price shocks and interest rate hikes, can exacerbate the adverse effects of these determinants. Market risk indicators, such as bond spreads, credit default swap (CDS) spreads, and rating changes can generally be viewed as predictors of the risk of a debt restructuring and default. Restructurings often follow or precede banking and currency crises and are associated with a decline in output, trade, and capital inflows Asonuma et al. $(2016,2018)$.

The IMF's Debt Sustainability Analysis (DSA) is an important tool to assess the potential need and scope of a sovereign debt restructuring. The public DSA analyzes the conditions under which a government's primary balance (the budget balance excluding interest payments) is sufficiently high to stabilize or reduce the public debt-to-GDP ratio. The external DSA assesses the same with respect to current account balance to stabilize or reduce the external debt-to-GDP ratio. Two key variables drive the DSA results: real interest rate (borrowing costs) and real growth rate. The larger the interest-growth differential, the higher the primary budget or current account balance needed to stabilize the debt-to-GDP ratios. Other indicators that may inform the DSA are, for instance, gross financing needs, debt structure and macro-realism.

Risk spillovers to and from the financial sector can play a major role in the decision for a sovereign debt restructuring. Sovereign debt restructurings can imply "top-down" risk spillovers, and cause losses to banks and investment funds, including pension funds, domestically and across borders, especially when they hold government debt or if they have sold (that is, have taken a short position on the country's bonds) sovereign CDSs. In this regard, some countries have launched a financial sector stability fund prior to their sovereign debt restructurings (for example, Jamaica 2010; St. Kitts and Nevis 2011-12) to possibly provide liquidity to financial institutions suffering losses from the exchange.

The scope of haircuts (creditor losses in PV terms) in bond restructurings has varied substantially, ranging from under 10 percent (for example, Uruguay in 2003, Dominican Republic in 2004-05) to over 80 percent (for example, Dominica in 2004, Ecuador in 2008-09, Seychelles in 2008-10, Cote D'Ivoire in 2000-10, and Greece in 2011-12). Evidence has shown

IMF (2013) defines solvency concerns as those such that a debtor country is no longer able to meet the present value of its debt obligations without indefinitely accumulating debt, and liquidity concerns as those such that the debtor country's liquidity assets and available financing are insufficient to meet or roll over its maturing obligations. 
that the size of the haircut in a restructuring is positively correlated with years of exclusion from capital markets and post-restructuring borrowing costs. In particular, higher haircuts (lower recovery values) are associated with longer periods of market exclusion and higher spreads after a crisis (Das et al., 2012; Cruces and Trebesch, 2013). ${ }^{3}$

In general, debt renegotiations have become quicker and less disputed since the 1990s. Most bond exchanges have been completed within one or two years, although sovereign bondholders tend to be dispersed. Consultations with creditor committees - normally comprised of groups of five to 20 representative bondholders - have been useful in tailoring an exchange offer that suited both creditor and debtor demands and increased participation (Asonuma and Joo, 2017). High participation rates (of more than 90 percent) have been featured in recent sovereign bond exchanges. ${ }^{4}$ Further, offering a menu of debt exchange options - in line with creditors' objectives and needs-has proven effective in past exchanges, as it has allowed creditors to choose their preferred type of new instrument, thereby incentivizing participation.

Among contractual issues, Collective Action Clauses (CACs) have been contained in the majority of international bonds by emerging market sovereigns, in particular those issued under New York and English law. While CACs can facilitate the restructuring process, their presence is no guarantee for a quick debt exchange with high participation. Other legal provisions and exchange characteristics can play an important role as well, in particular exit consents, aggregation clauses, and minimum participation thresholds. The problem of creditor holdouts in bond restructurings is less pervasive than commonly thought. In recent years, there have been only two exchanges with a large share of holdouts: Argentina (2005) and Dominica (2004). Further, litigation in the context of emerging market bond restructurings remains rare, except in the case of Argentina, while new evidence shows that the number of successful attachments of sovereign assets, that is, court-ordered asset seizures, is small compared to the number of cases filed.

Also, domestic bond restructurings are similar to foreign bond restructurings in many respects (Asonuma and Papaioannou, 2016). One difference lies in the creditor structure, as financial institutions in the debtor country may be the group most affected by a domestic restructuring. However, contrary to what is commonly believed, domestic investors were also heavily involved in a number of recent foreign bond restructurings. In Argentina (2005) and Uruguay (2003), domestic financial institutions constituted the main holders of the government's international bonds. On average, domestic bond exchanges could be implemented quicker than related external debt restructurings. A likely explanation is that debtor countries can set domestic regulatory incentives to convince domestic banks or investment funds to participate. Despite this, creditor participation was lower, on average, compared to external debt restructurings, while the size of haircuts was similar in most cases.

The rest of the paper is organized as follows. Section 2 briefly overviews both the debt issues in the Caribbean and the literature of sovereign debt restructurings. Sections 3 and 4 investigate the causes, processes, IMF engagement, and outcomes of the two debt restructurings in 2004-06 and 2013-15, respectively. Section 5 compares key elements between Grenada's 2004-06 and 2013-15 restructurings. The paper draws lessons from Grenada's experience in Section 6. Finally, conclusions are presented in Section 7.

\footnotetext{
Asonuma (2016) also shows that higher NPV haircuts (smaller recovery rates) at renegotiation are associated with larger (smaller) increases in yield spreads, reflecting trade-offs of the sovereign debtors and the creditors.

4 This may also be due to the acceptance of sovereign debtors' and independent advisers' proactive engagement with creditors.
} 


\section{BRIEF LITERATURE REVIEW}

Several recent studies have focused on the policy debate relating to debt sustainability and debt restructurings in the Caribbean. ${ }^{5}$ The IMF (2013) provides a general overview of IMF policies and practices based on recent experiences from sovereign debt restructurings in the Caribbean. ${ }^{6}$ Jahan (2013) demonstrates some common features and differences in three prominent debt restructurings in the Caribbean. ${ }^{7,8}$ Diaz-Cassou et al. (2008) and Erce (2013) examine the role played by the IMF during sovereign debt restructurings in the region. Focusing on countryspecific issues over longer horizons, Asonuma et al. (2017) discuss Belize's two sequential debt restructurings and debt sustainability considerations without IMF-supported programs. The present paper fills a gap in the literature of sovereign debt restructurings by focusing specifically on Grenada's two sequential restructurings with IMF-supported programs.

More broadly, a number of sovereign debt restructuring episodes have been analyzed during the past decade. ${ }^{9}$ Among these relevant studies, Sturzenegger and Zettelmeyer (2006) presents detailed histories of the defaults implemented and debt crises in seven emerging markets during 1998-2005, examining, in particular, surrounding political events, policy actions, IMF-supported programs, and incurred creditor losses. ${ }^{10}$ Based on an enlarged sample of debt restructurings over 1950-2010, Das et al. (2012) present some new stylized facts on the outcome and process of debt restructurings, including on the size of net present value (NPV) haircuts, creditor participation, and legal aspects. Our paper adds to the existing literature by covering, in the context of Grenada's two restructuring episodes, details of both private (external and domestic) and official external debt restructurings and associated IMF-supported programs.

Our study on Grenada's two recent restructurings relates to empirical and theoretical literature on serial sovereign debt restructurings (for example, Reinhart et al., 2003; Reinhart and Rogoff, 2005; Eichengreen et al., 2005a, 2005b; Catao et al., 2009; and Asonuma, 2016). In the empirical sphere, Reinhart et al. (2003) and Reinhart and Rogoff (2005) explore empirically the role of past credit history in debt intolerance. ${ }^{11}$ Catao et al. (2009) and Asonuma (2016) show that past defaulters are more likely to default relative to non-defaulters - countries that have not experienced either defaults or restructurings. Among recent theoretical studies, Catao et al. (2009) indicate that a vicious cycle in sovereign credit events arises from output persistence combined with asymmetric information about output shocks. In contrast, Asonuma (2016) shows that outcomes of previous debt restructurings influence the creditworthiness of sovereigns through increased borrowing costs. We contribute to the strand of literature on case studies of serial sovereign debt restructurings by analyzing in depth Grenada's two serial debt restructurings with regard to their causes, processes, and outcomes.

\footnotetext{
See Schipket et al. (2013).

6 Belize (2006-07 and 2012-13), the Dominican Republic (2004-05), Grenada (2004-06), Jamaica (2010, 2013), and St. Kitts and Nevis (2011-12).

Belize (2006-07), the Dominican Republic (2004-05), and Jamaica (2010).

Okwuokei and Van Selm (2017) provide an overview of selective recent restructurings in the region.

See Reinhart and Rogoff (2009), Sturzenegger and Zettelmeyer (2006), Finger and Mecagni (2007), Diaz-Cassou et al. (2008), Panizza et al. (2009), Das et al. (2012), Duggar (2013), Erce (2013), Cruces and Trebesch (2013), Asonuma and Trebesch (2016), and survey by Tomz and Wright (2013).

10 In a similar approach, Diaz-Cassou et al. (2008), Finger and Mecagni (2007), and Erce (2013) review recent sovereign debt restructurings and IMF-supported programs in the late-1990s and 2000s.

11 Eichengreen et al. (2005a, 2005b) explain that countries with "original sin" must pay an additional risk premium when they borrow and increase their solvency risks, since the financial market acknowledges that their inability to repay is a source of financial fragility.
} 


\section{GRENADA'S 2004-06 DEBT RESTRUCTURING ${ }^{12}$}

The 2004-06 debt restructuring achieved liquidity relief in a preemptive, collaborative, broadly transparent manner, but left solvency concerns unresolved. ${ }^{13}$ Prior to the debt restructuring, Grenada experienced a period of fiscal expansion and was hit by Hurricane Ivan in September 2004, which resulted in a substantial contraction in GDP. A "weakly preemptive" private debt restructuring — completed outside an IMF-supported program — was considered as relatively comprehensive and fair, enabling the authorities to reach agreements with both domestic and external creditors, despite broad creditor structure. Although the debt restructuring provided Grenada with substantial liquidity relief through maturity extension and coupon reduction over the short term, underlying debt sustainability concerns were not addressed.

\subsection{Background}

Grenada's growth decelerated and its volatility increased in the early 2000s after experiencing a relatively robust trend over the two and a half decades since its independence in 1974. Growth averaged 4 $1 \frac{1}{2}$ percent over 1980-99-shifting the country to the upper-middle income group - supported by preferential access to EU markets for its agricultural products and the country's initial entry into the North American and European tourism markets. However, average economic growth slowed to 4 percent over 1999-2004 and the variability of growth rate increased: in 2001, the economy experienced contraction with the growth rate at 2 percent of GDP, followed by high growth in 2002 and 2003 at $3 \frac{1}{2}$ and $9 \frac{1}{2}$ percent, respectively, and again a negative growth of 1 percent in 2004, increasing uncertainty. The erosion of trade preferences with Europe, terms of trade shocks, reduced fiscal space, excessive real wage growth, and emigration of skilled labor triggered the slowdown. While the tourism sector has been the dominant engine of growth, the concentration in this sector also made growth volatile and vulnerable due to the heavy reliance on imports and susceptibility to global shocks, particularly a decline in tourist arrivals from advanced countries.

Expansionary fiscal policy to counteract slowing growth led to a rapid buildup of debt by 2002. While the additional spending was mainly on capital projects, the impact on growth was limited, reflecting the low fiscal multiplier effect. The increased capital expenditure was financed by both external and domestic borrowing, leading to an elevation of interest payments (doubled in 2002 over 1999). Total public debt increased from 35 to 80 percent of GDP between 1999 and 2002. The rise in indebtedness severely reduced fiscal buffers to counteract shocks and put a further drag on growth.

Facing increasing financing needs, the government issued a US\$100 million international bond in June 2002 (nearly 25 percent of GDP). The 10-year US\$-denominated international bond yielded 9.5 percent and was priced at 475 basis points above the 10 -year US Treasury's. The proceeds were used to retire more expensive debt (including financial leases), clear arrears, and finance high-priority investment projects. The bond issuance was at odds with the government's debt management strategy, which prioritized concessional borrowing from multilateral and official bilateral sources, strictly controlling the granting of debt guarantees to public enterprises and the private sector, and continued adherence to the policy of prior approval by the Ministry of Finance for any borrowing by the public enterprises. As a result, external debt rose by over 20 percentage points of GDP to 62 percent at end-2002. Standard \& Poor's (S\&P) rated Grenada's foreign currency debt at BB-, with a stable outlook in March 2002, and reaffirmed the rating in June 2004.

\footnotetext{
12 Grenada's 2004-06 debt restructuring refers to the private debt restructuring completed in November 2005 and official debt restructuring completed in May 2006.

13 Asonuma and Trebesch (2016) define Grenada's 2004-06 private debt restructuring as "weakly preemptive," as some payments were missed, but only temporarily and after the start of formal or informal negotiations with creditor representatives (no unilateral default).
} 
Although in smaller amounts, Grenada also tapped the domestic market over 2003-04. In late 2003, Grenada issued EC $\$ 15$ million in 91-day Treasury bills (T-bills) at 5.5 percent on the Regional Government Securities Market (RGSM). This was replaced with a EC\$24 million 365-day T-bill issuance at 5.5 percent in the following year, resulting in a net borrowing in the RGSM of EC $\$ 9$ million. In addition, in December 2002, the government issued a EC $\$ 15$ million domestic bond with coupon rate of 9.75 percent and maturity of 11 years and in February 2004 a US\$5.5 million bond with coupon rate of 7.5 percent and maturity of 10 years. Both bonds were placed through domestic merchant banks.

Two devastating hurricanes, Ivan in 2004 and Emily in 2005, hit Grenada and caused unprecedented damages. In particular, Hurricane Ivan — one of the strongest storms ever recorded in the Caribbean - resulted in damages estimated at US\$900 million, equivalent to 200 percent of GDP, according to the Organization of Eastern Caribbean States (OECS) assessment. About two-thirds of this amount was to the housing stock, of which only 30 percent had some form of insurance coverage. Tourism and agriculture, the two major sources of export earnings, were also severely impacted, with the hurricane wiping out the entire nutmeg crop. Public debt stood at 130 percent of GDP at end-2004, while the IMF had projected that it would continue its upward dynamics, reaching nearly 150 percent by 2010 .

\subsection{Process}

\subsubsection{Private Debt Restructuring (Domestic and External) ${ }^{14}$}

On October 1, 2004, the government announced its intention to solve debt sustainability concerns and seek "the cooperation of creditors." The announcement informed the need for major reconstruction and rehabilitation efforts requiring considerable external assistance. The government also sought assistance from multilateral creditors - the Caribbean Development Bank (CDB), the IMF, and the World Bank - and initiated discussions with all official bilateral creditors. The stated objective was to return Grenada to a position of economic stabilization and debt sustainability.

The restructuring was undertaken preemptively, with subsequent arrears occurring due to suspension of coupon payments during the negotiation stage. Prior to its announcement in October 2004, the government had remained current on its debt obligations until the interest payments on the international bond were missed in December. Immediately following the missed payments, Grenada was downgraded to "selective default" (SD) by S\&P. In January 2005, the government contracted legal and financial advisors to assist in the formulation of a comprehensive debt reduction strategy that would ensure the sovereign's interests during the negotiation. ${ }^{15}$

The authorities targeted both external and domestic private debt, discriminating against external official creditors and holders of T-bills (Figure 1). The authorities sought to restructure all of the government's bond indebtedness, external commercial loans, and guaranteed debt. The government approached its bilateral creditors, asking them for full debt forgiveness or - at a minimum - for relief on comparable terms with commercial creditors. However, bilateral creditors preferred to have an IMF-supported program proceeding with a debt relief operation (IMF, 2005). T-bills were excluded from the debt restructuring because they were needed to enable financing the daily government operations during the negotiations. Burden sharing by multilateral creditors was expected through commitment of new credit. ${ }^{16,17}$

\footnotetext{
14 In the case of Grenada, classifications of domestic and external debt at the time of debt exchange in November 2005 are on a residence basis (Grenada Ministry of Finance, 2005).

15 Cleary Gottlieb Steen and Hamilton LLP acted as the legal advisors, and Bear Sterns \& Co. Inc. was hired as the financial advisor (Grenada Ministry of Finance, 2005, p. 95).

16 Grenada Ministry of Finance (2005, p. 2).

17 Multilateral claims are considered senior to other claims and are excluded from the exchange.
} 
Figure 1

Grenada's Public Debt, June 2004

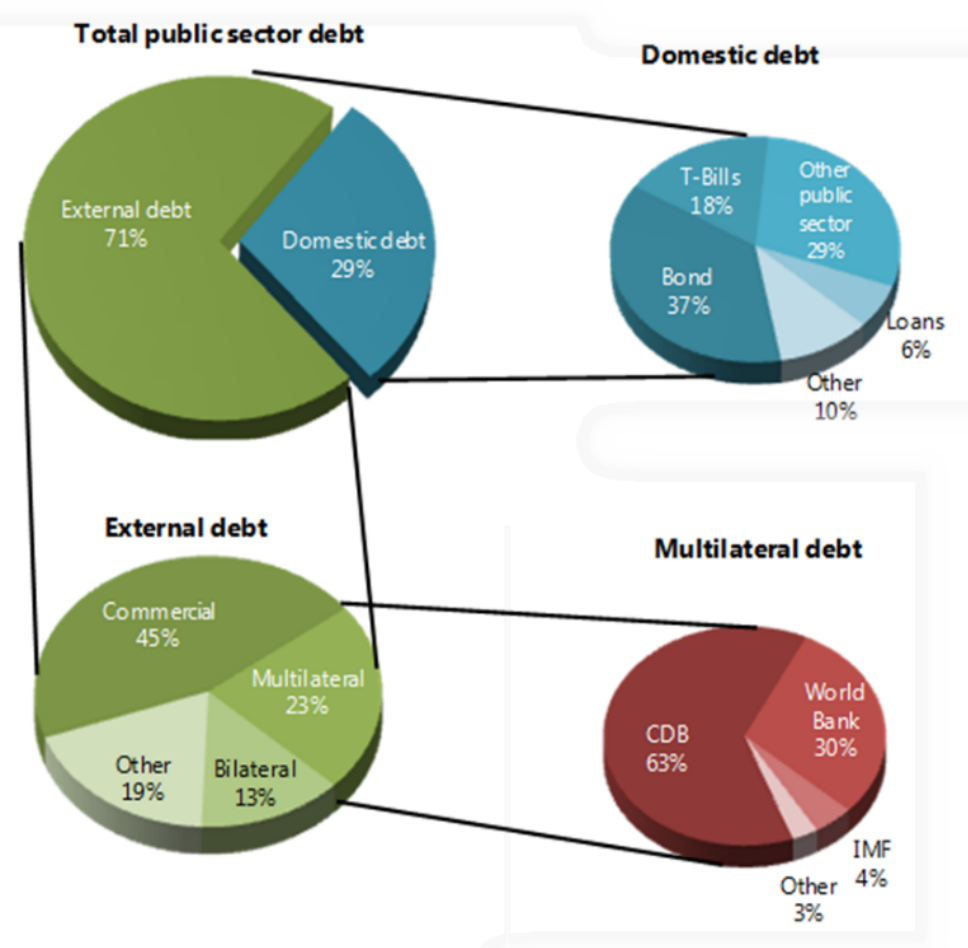

Source: IMF (2004).

The existence of a broad-based creditor committee and the authorities' effective communication strategy facilitated the negotiation process. ${ }^{18}$ In April 2005, a creditor committee representing a majority of Grenada's commercial debt obligations was formed that accounted for about 70 percent of the eligible commercial external debt (equivalent to US\$171.6 million). ${ }^{19}$ The authorities engaged in open dialogue with the creditor committee and maintained transparency in the dissemination of all relevant macroeconomic data. The focus of the negotiations was mainly near-term cash flow relief, reflecting the large reconstruction needs. In May 2005, the authorities released their debt sustainability analysis (DSA) showing financing gaps through the medium term, broadly in line with the IMF staff assessment.

With an IMF-supported program envisaged in the medium-term forecast, the authorities' DSA showed that public debt was on a sustainable path. Under the program scenario, public debt was expected to decline from 120 percent of GDP in 2005 to 60 percent of GDP in 2015. A large part of this adjustment was to be achieved during the program period, so that by end-2008 the public debt would amount to less than 95 percent of GDP. The expected decline was largely a function of the sharp improvement in the primary balance during 2006-08 and a pickup in GDP growth. However, accomplishment of both fiscal and growth objectives were crucial. Failure to adhere to program targets could rapidly result in an unsustainable debt trajectory, and a significant external shock, such as another major hurricane, could have a similar adverse effect.

On September 9, 2005, after intensive dialogue with private creditors, a debt-restructuring proposal was launched. ${ }^{20}$ Commercial debt eligible for the exchange comprised of (1) domestic

\footnotetext{
18 The creation of the creditor committee differs from those formed in the 1980s and 1990s in certain aspects: establishing certain criteria for formation of committee and its procedural rules and incorporating elements that enhanced dialogue and participation among creditors in past restructurings cases (Buchheit, 2009; Li et al. 2010).

19 See Jahan (2013) for further details.

20 The debt exchange operation was initially scheduled to close on October 7, 2005, and later extended to October 14, 2005.
} 
claims of US\$76.8 million (US\$5.5 million US\$-denominated claims and US\$71.0 million EC\$-denominated claims) ${ }^{21}$; (2) external claims of US\$171.6 million (US\$155.7 million in US\$-denominated claims and US\$16 million EC \$-denominated claims). ${ }^{22}$ These claims include the capitalization of past-due interest accrued over the 10 months prior to the restructuring. The restructuring was executed through an exchange, with two instruments, EC\$-denominated bond for most of the domestic claims and US\$-denominated bond for most of the external claims. The EC\$-denominated bond was issued under domestic law, and the US\$-denominated bond was issued under foreign law (New York law). Both bonds were par-bonds (that is, no principal haircut) with a final maturity in 2025, with amortization starting in 2020, and a step-up coupon structure starting in 2011 (Table 2). Given this step-up coupon structure, the government anticipated increases in debt services in 2012 (Figure 3).

On November 15, 2005, the commercial debt restructuring was concluded, covering the equivalent of approximately 47 percent of the total public debt. The details of financial and legal terms at the exchange were the following (Table 1):

- No principal haircut. Approximately US\$248 million of new EC\$-denominated and US\$-denominated bonds (excluding those for guaranteed loans) were issued without facevalue reduction.

- Capitalization of past-due interest. Past-due interest on any eligible claims is included as a portion of tendered eligible claims.

- Coupon rate reduction. Due to a step-up coupon structure, average coupon rates of the new bond over the life of the bond are lowered by 2.3 percent. Coupon rates for new instruments are 1 percent until 2008, 2.5 percent until 2011, 4.5 percent until 2013, 6 percent until 2015, 8 percent until 2017, 8.5 percent until 2018, and 9 percent until maturity.

- Maturity extension and change in repayment structure. Maturity was extended by 11.7 years on average. Contrary to payments due at maturity for all old instruments (100 percent of total outstanding), the new bond is an amortizing bond commencing in September 2020 (constant share of remaining outstanding).

- NPV and market haircuts. ${ }^{23}$ Using a discount rate of 8.9 percent, the NPV haircut was 38.4 percent, while the market haircut was 40.5 percent. There was only a marginal difference (3 percent) in NPV haircuts between domestic and external creditors (Figure 2). ${ }^{24}$

- No use of CACs and exit consent. Contrary to other restructuring cases in the Caribbean, for instance Belize and the Dominican Republic, no CACs were triggered and no exit consent was used. $^{25}$

- Minimum participation requirement. The exchange offer specified the minimum level of overall participation requirement as at least 85 percent of total principal outstanding amount of eligible claims.

\footnotetext{
21 Domestic US\$-denominated claims comprised one bond, whereas EC\$-denominated claims comprised nine bonds, six commercial loans, and one guaranteed claim.

22 External US\$-denominated claims comprised five bonds, two commercial loans, and four guaranteed claims, whereas EC \$-denominated claims comprised two bonds.

23 NPV haircut is defined as (1 - Present value of new debt/Present value of old debt), as in Sturzenegger and Zettelmeyer (2006, 2008). Present value of new debt and old debt is computed with the same discount rate. Following Sturzenegger and Zettelmeyer (2006, 2008), we use the exit yield at the completion of exchange. On the contrary, market haircut is defined as (1 - Present value of new debt/Face value of old debt).

24 Asonuma et al. (2017a) find haircuts on shorter-term debt tend to be larger than those on longer-term debt in Grenada 2004-05 private debt restructuring.

25 See Asonuma et al. (2017b) for the Belize debt restructurings in 2006-07 and 2012-13, and Das et al. (2012) and Jahan (2013) for the Dominican Republic and St. Kitts and Nevis restructurings.
} 
Table 1

Grenada’s Commercial Debt Restructuring, 2004-06: Deal Structure

\begin{tabular}{|c|c|c|c|c|c|}
\hline \multirow{3}{*}{$\begin{array}{l}\text { Domestic or External } \\
\text { US\$ or EC\$ denominated }\end{array}$} & \multicolumn{4}{|c|}{ Old instruments } & \multirow{3}{*}{$\begin{array}{c}\text { New Instrument } \\
\text { External / Domestic } \\
\text { US\$ / EC\$ }\end{array}$} \\
\hline & \multicolumn{2}{|c|}{ External } & \multicolumn{2}{|c|}{ Domestic } & \\
\hline & US\$ & $\mathrm{EC} \$$ & US\$ & $\mathrm{EC} \$$ & \\
\hline Instruments & $\begin{array}{c}\text { Bonds/Bank } \\
\text { loans }\end{array}$ & Bonds & Bonds & $\begin{array}{c}\text { Bonds/Bank } \\
\text { loans }\end{array}$ & Bonds \\
\hline Face value (US\$ mil.) & 155.7 & 16.0 & 5.5 & 71.3 & 248.5 \\
\hline Face value haircut & $0 \%$ & $0 \%$ & $0 \%$ & $0 \%$ & - \\
\hline Maturity & $2006-14$ & $2012-15$ & 2014 & $1998-2018$ & 2025 \\
\hline Grace period (years) & $\mathrm{N} / \mathrm{A}$ & $\mathrm{N} / \mathrm{A}$ & $\mathrm{N} / \mathrm{A}$ & $\mathrm{N} / \mathrm{A}$ & 15 \\
\hline Remaining maturity (years) & 4.7 & 8.9 & 9.0 & 4.3 & 20 \\
\hline Coupon ${ }^{1)}$ & Fixed $4.8-10 \%$ & Fixed $8.85-10 \%$ & Fixed $7.5 \%$ & Fixed $6-10 \%$ & Step-up coupon \\
\hline Repayment style & Bullet & Bullet & Bullet & Bullet & Amortizing \\
\hline Present value on $12 / 2005^{2) 3}$ ) & $98 \%$ & $102 \%$ & $92 \%$ & $94 \%$ & $59 \%$ \\
\hline NPV haircut 4) 5) & $39 \%$ & $42 \%$ & $35 \%$ & $36 \%$ & - \\
\hline
\end{tabular}

1) Coupon rates for new instruments are $1 \%$ until 2008, $2.5 \%$ until 2011, $4.5 \%$ until 2013, $6 \%$ until 2015, $8 \%$ until 2017, $8.5 \%$ until $2018,9.0 \%$ until maturity.

2) Discount rate of 8.9 percent which was exit yield at completion of exchange (on 12/30/2005 - the first transaction dayyields were recorded after completion of exchange).

3) Weighted average of all instruments following in the category based on outstanding as of 9/2005.

4) NVP is defined as 1-Present value of new debt/Present value of old debt as in Sturzenegger and Zettelmeyer (2005, 2007). Present value of new debt and old debt is computed with the same discount rate.

5) Weighted average of all instruments following in the category based on outstanding as of 9/2005.

Sources: Grenada authorities and authors' calculations.

The debt exchange achieved 91 percent participation of eligible debt owed to private creditors. The participation rate was 93 percent on the external claims and 86 percent on the domestic claims. Although the participation rate in the debt exchange offer was high, there were holdouts. Despite concerns about future debt distress, creditors were motivated to accept the offer because (1) the return profile was rewarding enough based on a risk-adjusted assessment of the positive outlook of Grenada's economy and the then-favorable global environment; (2) potential costs of holding out were high and it was less attractive to take legal actions, even with the expectation of an ultimate success; and (3) the original bonds had become illiquid, and thus any outright sales would be difficult.

\section{Figure 2}

Grenada's Private Debt Restructuring, 2004-06: NPV Haircuts ${ }^{1)}$ 2)

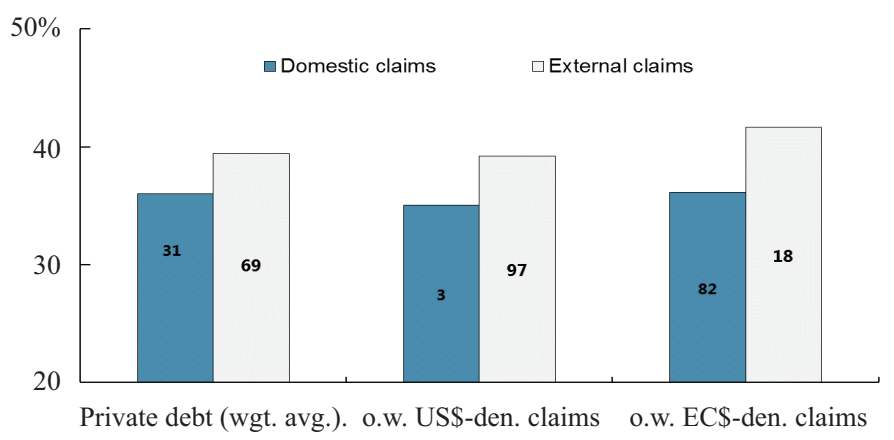

\footnotetext{
1) Using a discount rate of 8.9 percent, which was the exit yield of EC\$ bonds on December 30, 2005.

2) Figures on bars represent shares of claims in the corresponding category.

Source: Authors' calculations based on Grenadian statistics.
} 
Grenada continued to negotiate effectively and efficiently with the creditors that did not participate in the debt exchange (IMF, 2006). ${ }^{26}$ Grenada determined that it did not want to repudiate debt held by nonparticipating creditors. However, neither did it have the resources to pay untendered eligible claims on the original terms. Therefore, the authorities decided to follow the example of the Dominican debt restructuring. ${ }^{27}$ Further, despite a large variety of restructured instruments with variations in NPV haircuts, the exchange to two single bonds did not raise significant inter-creditor equity issues.

Five guarantees were eligible for the debt restructuring, of which four were exchanged for the new central government bonds with guarantees discharged. Because these guarantees did not constitute central government direct debt, the government could not restructure them unless they were called. The government therefore took the following approach: ${ }^{28}(1)$ beneficiaries were given the option to call the guarantee prior to the expiration of the exchange offer. The face value of the called guarantee would then be exchange for the new bond; (2) a beneficiary calling a guarantee in these circumstances was required to subrogate Grenada to all of the beneficiary's claims against the primary obligor and any collateral securing the debt of the underlying project; and (3) if the beneficiary decided not to call, any subsequent call on the guarantee would be discharged by the delivery of the exchanged bonds on terms comparable to those reflected in the exchange offer. The last condition was designed to discourage guaranteed bondholders from attempting to ride out the restructuring in the hope that the guarantees could be called and would be fully paid after the exchange offer closed. It was also intended to achieve a parity of treatment among creditors.

\subsubsection{Official Debt Restructuring}

Parallel with the negotiation with private creditors, the authorities approached their bilateral official creditors (IMF, 2005). The authorities requested full debt forgiveness or - at a minimumrelief on comparable terms with commercial creditors. However, some Paris Club creditors preferred to have an IMF-supported program in place before they would consider a comprehensive debt relief.

On May 12, 2006, subsequent to the private debt exchange, the Paris Club agreed to a debt treatment of its US\$16 million claims (as of January 2006). ${ }^{29}$ The agreement comprised (1) the treatment of arrears as of December 31, 2005, and (2) the treatment of maturities falling due between January 1, 2006, and December 31, 2009 (over the duration of the IMF's PRGF arrangement, 2006-08).

The treatment under Classic terms consisted of the following:

(1) Repayment of non-ODA credits over 12 years with a five-year grace period.

(2) Repayment of ODA credits over 12 years with a five-year grace period.

Losses to Paris Club creditors were substantially smaller than those to private sector creditors. NPV haircuts on Paris Club loans were estimated at 13.2 percent using a discount rate of 5.6 percent, which was the market rate prevailing at the time of the exchange (OECD Commercial

\footnotetext{
26 About half of the nonparticipating eligible external claims pertained to a single creditor with whom the authorities had established contact and who they continued to offer a settlement on the same terms as the participants in the exchange had received. The other half pertained to about 5 percent of holders of a US\$100 million international bond issued in 2002. In this case, the identity of the nonparticipating creditors was unknown and the authorities were making efforts to find and engage these creditors.

27 In the case of Dominica, the authorities instructed the ECCB to open a special escrow account for debt payments. While the Dominican authorities continued to work constructively with the remaining creditors, the purpose of the new ECCB account was to receive deposits of interest earnings on claims held by creditors that had not yet participated in the restructuring exercise (on the assumption that they would eventually participate). For such creditors, interest accrued up to June 11, 2004 (the original closing date), under the original terms. Thereafter, the Dominican authorities treated the outstanding principal amounts as if they had been converted into the bond envisaged under the exchange offer and, as payments fell due, made payments into the escrow accounts under the restructured terms.

28 See Buchheit and Karpinski (2006).

29 Paris Club (2006).
} 
Interest Reference Rate) ${ }^{30}$ In general, the terms of the treatment offered to official creditors under Paris Club agreements were more favorable (to creditors) than that received by private creditors (IMF, 2015). ${ }^{31}$

The government, however, could not reach an agreement with its largest bilateral creditor, the Export-Import Bank of Taiwan Province of China (Ex-Im Bank). ${ }^{32}$ In March 2006, the Ex-Im Bank filed a complaint against Grenada for the unpaid principal of US\$28 million in loans extended to Grenada (about a quarter of Grenada's total bilateral debt). In 2007, the Ex-Im Bank won a court ruling that included a court judgment for pre- and post-judgment interest and attorney's fees.

\subsection{IMF Engagement}

Hurricane Ivan created large fiscal and balance of payments financing needs and severely complicated fiscal efforts in September 2004. Prior to the hurricane, the authorities were making progress in addressing the fiscal and debt imbalances. Following Ivan, however, the government was deeply financially constrained to meet current fiscal obligations, including wage payments, and the overall fiscal deficit was anticipated to rise sharply. The loss of foreign exchange receipts from tourism alone was projected at over 8 percent of GDP. To meet their immediate financing needs, the authorities relied on external assistance, mainly grants. In the difficult circumstances, the authorities responded swiftly to mitigate the impact of the hurricane on the population and began to address the macroeconomic imbalances in a transparent manner.

The IMF responded to Grenada's financial needs after the hurricane through the Emergency Assistance for Natural Disasters Initiative (approved in November 2004, SDR 2.93 million or 25 percent of quota). Moreover, immediately after Hurricane Ivan, the authorities requested IMF support for their intention to formulate an appropriate medium-term adjustment program that combined fiscal consolidation, steps to restore growth, and a commitment to reach a cooperative solution with Grenada's creditors to reduce the country's debt burden (IMF 2005a).

In the debt restructuring with private sector creditors in 2004-06, the IMF played its role as an independent party to provide a debt sustainability assessment and cash flow analysis. It maintained close contact with both the authorities and their financial advisors, but not with creditors, during the restructuring process. In May 2004, the IMF mission released a statement acknowledging that the fiscal efforts were unlikely to be sufficient to achieve debt sustainability and that there was a need to pursue a comprehensive approach comprising fiscal adjustment, growth enhancing structural reforms, and debt management (IMF, 2004). At the request from the authorities of Grenada, the IMF issued an assessment letter to the international financial community on July 20, 2005, before the launch of the exchange offer (IMF, 2005b). The letter noted that achieving a high degree of participation in the proposed exchange offer would contribute to improving debt dynamics toward sustainability and achieving "an orderly process of financial and external adjustment."

Negotiation with the IMF on an IMF-supported program was prolonged due to several factors. After the two hurricanes, in 2004 and 2005, the authorities' efforts and limited resources were focused on relief, rehabilitation, and reconstruction activities. As such, they were not in a position to finalize the specifics of an IMF-supported program. Moreover, the authorities were also finalizing the lengthy commercial debt restructuring process. Since the debt discussions

\footnotetext{
30 IMF (2015c). The 2 percent coupon rate on ODA loans is based on a simple average of concessional terms provided by Paris Club creditors to a sample of HIPC debt restructuring episodes. The coupon rate on non-ODA loans is assumed to be market based and is calculated as the sixmonth average of the Commercial Interest Reference rates (CIRR) as published by the OECD.

31 Classic terms are the standard terms applied to a debtor country coming to the Paris Club. Credits (whether ODA or non-ODA) are rescheduled at the appropriate market rate, with a repayment profile negotiated on a case-by-case basis.

32 Taiwan Province of China is a non-Paris Club creditor. Grenada severed its diplomatic relations with Taiwan Province of China, the largest bilateral creditor at the time of the restructuring in December 2004, and established diplomatic relations with the People's Republic of China.
} 
were protracted, the debt exchange with commercial creditors took place outside the context of an IMF arrangement. Furthermore, the authorities planned to undertake several fiscal measures in conjunction with the 2006 budget. As a result, an Extended Credit Facility arrangement (previously called the Poverty Reduction and Growth Facility) for 90 percent of quota was agreed upon in April 2006. The ECF arrangement helped stabilize the economy through various channels: (1) limiting the fiscal deficit, (2) paving the way for a Paris Club debt rescheduling in 2006, and (3) catalyzing additional financing from multilateral donors.

\subsection{Outcomes}

The debt restructuring with private sector creditors provided significant liquidity relief in NPV terms, but Grenada's debt sutainability remained precarious, for a host of reasons. These include lower-than-expected growth rates in the period following the restructuring due to adverse shocks, which in turn led to the government's expansionary policy response and subsequently deterioration in the debt ratio. This clearly suggests that the first restructuring did not provide enough of a cushion for fiscal and growth slippages. If the program assumptions had been realized, it would have been adequate. Otherwise, face value cuts should have been needed to create such a cushion. Meanwhile, the average maturity of public external debt was extended from 8.3 years before the exchange to 20 years, which resulted in a substantial decline in debt service in the short run (Figure 3). Debt service relief amounted to US\$22.4 million (including the missed interest payments) in 2005 (3.2 percent of GDP) and about US\$18.9 million (2.5 percent of GDP) per year from 2006 to 2010 . However, with no nominal haircut, the outstanding debt remained high, at 87.7 percent of GDP in 2005, declining only temporarily from 95 percent of GDP in 2004 and remaining high, around 90 percent of GDP, thereafter.

Figure 3

Grenada's Private Debt Restructuring, 2004-06: Debt Service ${ }^{1)}$ (in millions of US dollars)

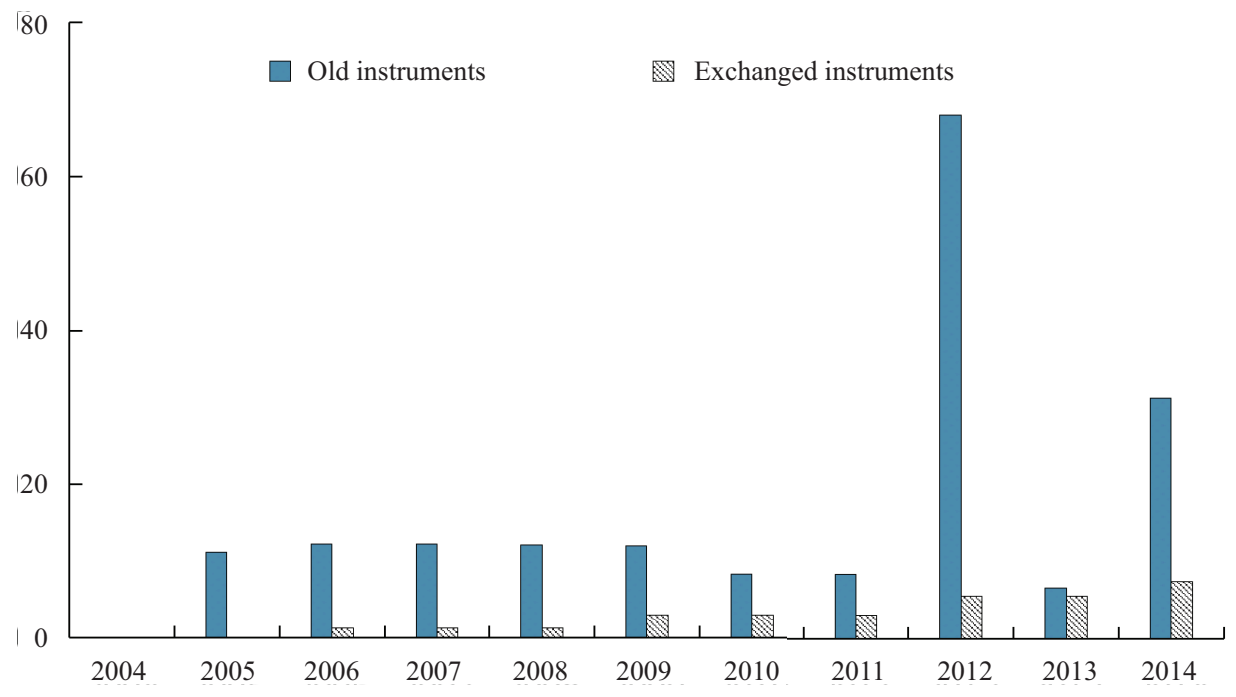

1) Debt service for old instruments excludes debt service of guaranteed debt.

Source: Grenadian authorities and authors' calculations.

Despite a substantial NPV haircut, Grenada enjoyed an immediate but small improvement in its forward-looking credit ratings: S\&P raised Grenada's credit rating to B- and to B- on its local currency and foreign currency debt from SD on November 18, 2005. These ratings, however, fell short of Grenada's B + and $\mathrm{B}+$ ratings before the announcement of restructuring in October 
2004. ${ }^{33}$ On April 2, 2007, the rating was downgraded to CCC+, with a stable outlook on foreign currency, and $\mathrm{C}$ on local currency debt following the late debt service payment to a local bank and mounting fiscal pressures in the first quarter of 2007.

On August 2, 2007, the rating was again uplifted to B-, due to the rectifying steps taken by the government to improve the management of debt repayments. Since completion of the exchange, the bond yields had been below 10 percent for 12 months (Figure 4).

Grenada did not issue new bonds other than in the RGSM and in the domestic market. Both the global financial crisis of 2007-08 and reoccurrence of debt restructurings in the Caribbean (Section VI) raised the risk aversion of private sector creditors, preventing new external commercial debt issuances. Grenada relied largely on official project financing from bilateral and multilateral creditors, including a budget support in the amount of US\$16.5 million from Trinidad and Tobago. Domestically, T-bills were issued through domestic private placements and in the RGSM; a EC\$30 million (equivalent to US\$11.1 million) domestic bond was issued in October 2007 under domestic law for the first time since the completion of private debt restructuring. The domestic bond was issued with maturity of five years and coupon rate of 7 percent.

\section{Figure 4}

Grenada's Private Debt Restructuring, 2004-06: Bond Yields and Credit Ratings

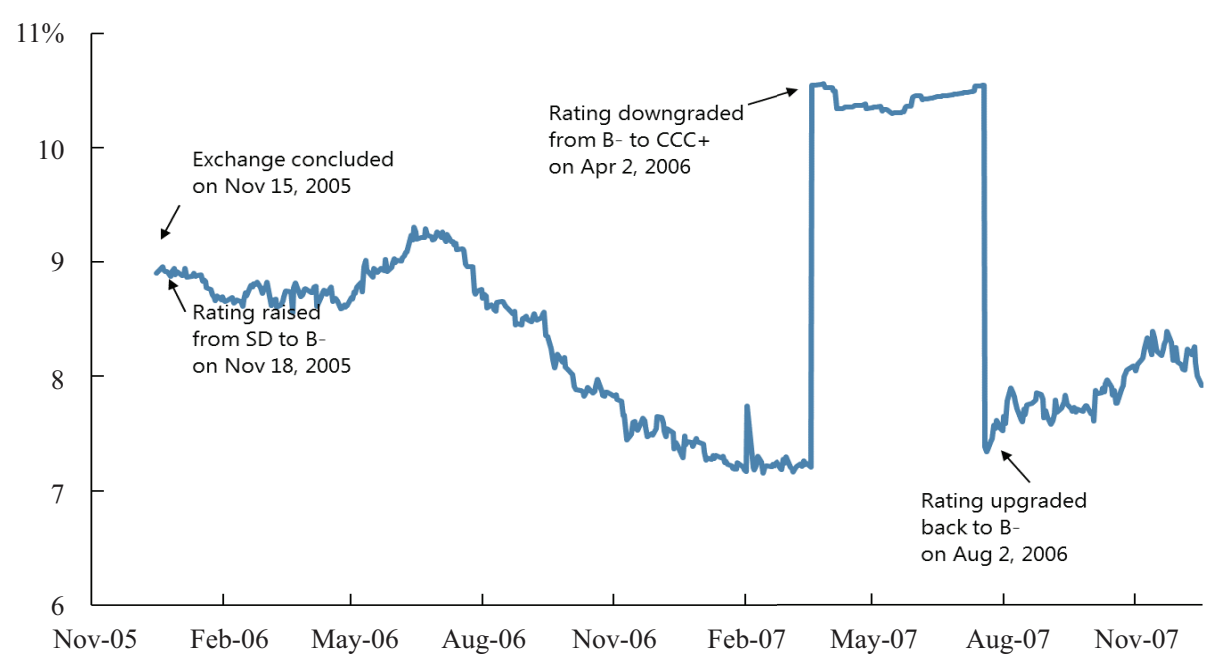

Source: Bloomberg.

\section{GrenadA's 2013-15 Debt RestruCturing ${ }^{34}$}

The 2013-15 debt restructuring involved debt relief and, more directly, addressed solvency issues. Prior to the debt restructuring, Grenada experienced a subdued post-hurricane economic recovery and accumulated large fiscal imbalances through countercyclical fiscal policies. The authorities proceeded with restructurings on private debt and followed with negotiations with official creditors under an IMF-supported program. A post-default restructuring with private creditors was relatively comprehensive, but was delayed due to broad creditor structure and a holdout from a major non-Paris Club creditor. While the Grenadian authorities received a substantial debt relief (face-value reductions), future market re-access remained uncertain.

Neither Moody's nor Fitch assigns ratings to Grenada.

34 Grenada's 2013-15 debt restructuring refers to the private debt restructuring completed in November 2015 and official debt restructuring completed in November 2015. 


\subsection{Background: Over 2005-13}

The global financial crisis reversed the already weak post-hurricane recovery and contributed to a deep economic crisis in Grenada by 2011-12. Grenada's economy was severely affected by the global financial crisis as the tourism and construction sectors collapsed, with the economic activity declining by over 8 percent from peak to trough (2008-12) before it had a chance to fully recover from the devastating Hurricane Ivan in 2004. This compares to a $1 \frac{1}{3}$ percent decline in emerging markets and a $51 / 3$ percent decline in the tourism-based Caribbean countries over the same period. An IMF-supported ECF program that started in 2010 went off track only after the first review because of the government's decision to resort to expansionary policy response.

Countercyclical policies during the economic crisis led to large fiscal imbalances. With no effective independent monetary and exchange rate policy toolkit, given the quasi-currency-board setup of the ECCU, the government resorted to fiscal policy as an attempt to counteract the negative impacts of the global financial crisis on Grenada. However, positive spillover of the expansionary policy was limited due to small fiscal multipliers of the small open island economy and longstanding competitiveness challenges. As a result, fiscal imbalances widened without a commensurate increase in economic growth, which contributed to an unsustainable fiscal situation, with public debt increased to over 100 percent of GDP by end-2012. The government's cash flows also came under severe pressure with growing financing constraints as multilateral financing dried up and domestic banks limited their exposure to the government. This in turn led to an accumulation of the government's arrears to domestic suppliers. At the start of the IMF-supported program in 2014, the public debt ratio was projected to reach over 134 percent of GDP by 2020 without fiscal adjustment and debt restructuring (IMF 2014a).

Despite some adjustments, persistent large current account deficits remained a significant risk to Grenada's external sustainability. Weak domestic demand during the economic crisis helped narrow the current account deficits, which, however, have been increasingly financed by debt, creating flows as foreign direct investments declined. As a result, Grenada's external debt (public and private) had increased by about 40 percent of GDP since 2007, to almost 150 percent of GDP in 2012, reflecting in part large accumulation of foreign liabilities of domestic banks through nonresident deposits and borrowing by foreign-owned banks from their headquarters. ${ }^{35}$

Grenada had not regained market access since the 2005 debt exchange. External financing was limited to multilateral and bilateral official sources with no new external commercial debt issued since the 2005 debt restructuring. On the domestic front, Grenada rolled over the existing 365day T-bill on the RGSM, but it was not until 2007 and again in 2009 and 2010 that they were able to raise meaningful net financing from the RGSM (Section V.D). It also issued a new serial bond (totaling EC \$11.5 million), with a coupon rate of 6 percent and portions issued throughout $2011 .{ }^{36}$ The bond was sold mostly to the National Insurance Scheme (NIS) and domestic insurance companies through private placements.

\subsection{Process}

\subsubsection{Private Sector Debt Restructuring}

On March 8, 2013, Grenada announced its intention to pursue a new "comprehensive and collaborative" debt restructuring. The announcement stated that debt issued in the RGSM and multilateral debt would be excluded from the restructuring. It stated that Grenada's intention was not to make coupon payments due on March 15, 2013, on the US\$ and EC\$ 2025 bonds. Prior to the announcement, Grenada had delayed the coupon payment due on September 15, 2012,

\footnotetext{
There are no official statistics for private sector external debt. IMF staff estimates are based on balance of payments statistics for the banking and non-bank private sectors.

36 This bond was approved by Parliament in 2010.
} 
although it was eventually paid shortly before the expiration of the grace period. Financing to pay for the coupon was obtained from local sources on a short-term basis, but further borrowing was no longer a viable option. S\&P lowered Grenada's foreign currency credit ratings to SD/SD from B-/B and local currency ratings to $\mathrm{CCC}+/ \mathrm{C}$ from B-/B on October 8, 2012. Subsequent to the delayed September 15, 2012, coupon payment, the foreign currency rating was raised to $\mathrm{CCC}+\mathrm{C}$, with a negative outlook on October 16, 2012. On March 12, 2013, the foreign and local currency ratings were again lowered to $\mathrm{SD} / \mathrm{SD}$.

Immediately following the announcement, the government contracted financial and legal advisors to assist them in the restructuring process. ${ }^{37}$ With the help of the financial and legal advisors, the government initiated discussions and maintained close contact with the creditor groups, including the creditor representative committee. The authorities also reached out to the bilateral official creditors and domestic creditors, and sought comparable treatment with the private sector creditors.

By April 2013, a bondholder's group was formed comprising a steering committee and an adhoc committee. The steering committee consisted of six of the largest bondholders (with reported approximate exposure of US\$168 million), and the ad-hoc committee (with reported approximate exposure of US\$32 million) represented a broader group of bondholders, together holding just over 75 percent of the outstanding US\$ and EC $\$ 2025$ bonds. The bondholder's group controlled almost 90 percent of the US\$ 2025 bond. The bondholders contracted Broadspan Capital to represent them in the restructuring negotiations.

Multilateral institutions provided the bulk of the new financing in 2014 and 2015. Disbursed loans from the CDB, the IMF, and the World Bank (WB) totaled more than US\$30 million annually in 2014 and 2015. In addition, disbursements of contracted but undisbursed loans from the WB and the $\mathrm{CDB}$ to finance ongoing projects provided the necessary liquidity to the government.

The standstill on debt service after the debt-restructuring announcement alleviated some of the financing pressures. Debt arrears accumulated through the nonpayment of interest on debt owed to private sector creditors, holders of privately placed T-bills (that is, not listed on the RGSM), Paris Club bilateral official creditors, and non-Paris Club bilateral official creditors. The government also accumulated arrears to domestic suppliers, public bodies, and membership fees to regional and international organizations. By end-2013, overall arrears increased to 15.3 percent of GDP, of which 10.7 percentage points were on external obligations and about 4.6 percentage points on domestic obligations.

One year after the announcement of the debt restructuring, in March 2014, Grenada published its initial financing estimates. The significant delay of the announcement was caused by a protracted negotiation for an IMF-supported program. It immediately followed the announcement of the staff level agreement on March 14, 2014, which would form the backbone of the anticipated Extended Credit Facility (ECF) arrangement. The publication discussed Grenada's homegrown reform program, which encompassed fiscal consolidation, overhaul of the fiscal framework legislation, structural reforms, and measures to strengthen financial system stability. Together with a comprehensive restructuring of the public debt, they aimed to place Grenada's public finances firmly on a sustainable footing. The publication reported medium-term macroeconomic projections and financing, including the financing gap that still needed to be filled after taking into account fiscal consolidation, but before debt restructuring. It also made clear that Grenada's public and publicly guaranteed debt owed to both private and official sector creditors - with the exception of the T-bills listed on the RGSM, overdraft facilities, and multilateral claims-would fall within the scope of the debt restructuring.

In April 2014, Grenada published two indicative debt restructuring options as background for future discussions with holders of its EC\$2025 bond (Table 2). The publication noted that

Clearly Gottlieb Steen \& Hamilton LLP was appointed to act as the legal advisor and White Oak Advisory as the financial advisor. 
the indicative options did not constitute an offer, but rather was intended as an indication of the type of restructuring terms that Grenada believed to be required to bridge the multiyear financing gap identified in the initial financing estimate published in March 2014. The IMF Staff Report published in July 2014 indicated that the published debt restructuring scenarios were consistent with achieving debt sustainability and reducing near-term debt servicing obligations. ${ }^{38}$ The same indicative options were presented to the Ex-Im Bank of Taiwan, along with a proposal on the treatment of outstanding arrears - despite ongoing litigation against Grenada, the Ex-Im Bank indicated its willingness in principle to participate in the debt restructuring.

Table 2

Grenada's Debt Restructuring, 2013-15: Indicative Scenarios, April 2014

\begin{tabular}{lcc}
\hline \hline & \multicolumn{2}{c}{ Indicative Scenarios } \\
\hline Option & Option 1 & Option 2 \\
Face value haircut & $60 \%$ & $50 \%$ \\
Grace period (years) & 0 & 2 \\
Final maturity (years) & 15 & 20 \\
Coupon & $6.5 \%$ & $5 \%$ \\
Repayment style & Equal installments & Increasing installments \\
Interest arrears & $60 \%$ reduction, & $50 \%$ reduction, \\
\hline \hline
\end{tabular}

Source: Grenadian authorities.

In March 2015, the Government of Grenada reached financial agreements with private creditors on the US\$ and EC\$ bonds (Table 3. Due to delays in the preparation of the legal documentation, the final launch of the debt exchange did not take place until October 5, 2015, when the offering memorandum of the new bonds was circulated. ${ }^{39}$ On November 12,2015 , Grenada announced the formal closing of the exchange offer involving the US\$ and EC\$ 2025 bonds. Tenders representing 94 percent of the US\$ 2025 bond and 100 percent of the EC\$ 2025 bond outstanding and eligible to vote for the exchange were received before the expiration date of the offer. Consistent with the CAC in the US\$ and EC\$ 2025 bonds (Box1), the entirety of those bonds were exchanged for new Grenada US\$ and EC\$ bonds due 2030 (the "2030 bonds"). The details of financial and legal terms at the exchange were the following (Table 3):

- Face-value reduction of 50 percent and 0 percent. Both external and non-NIS domestic bonds were issued with 50 percent face value reduction, but NIS domestic bonds were issued without face-value reduction.

- Capitalization of past-due interest. Past-due interest due on any eligible claims was included as a portion of tendered eligible claims.

- Changes in coupon structure. Coupon rates for new instruments were fixed at 7 percent for external and non-NIS domestic bonds and 3 percent for NIS domestic bonds.

- Maturity extension. Maturity was extended by five years for external and non-NIS domestic bonds and 10 years for NIS domestic bonds on average.

- NPV haircuts. Using a discount rate of 13.9 percent, the NPV haircuts were (1) 49 percent for external and non-NIS domestic bonds and (2) 59 percent for NIS domestic bonds.

- Use of CACs and no exit consent. CACs on US\$-denominated bonds were triggered, and no exit consent was used.

$38 \operatorname{IMF}(2014 \mathrm{a})$.

39 Grenada Ministry of Finance (2015). 
- Minimum participation requirement. The exchange offer specified the minimum level of overall participation requirement as at least 75 percent of the total principal outstanding amount of eligible claims.

- Hurricane clause and Citizenship by Investment Program revenue sharing clause (Appendix 1). These were two important innovations introduced in the new bond contract.

Table 3

Grenada's Private Debt Restructuring, 2013-15: Deal Structure

\begin{tabular}{|c|c|c|c|c|c|}
\hline \multirow[b]{2}{*}{ Domestic or External } & \multicolumn{3}{|c|}{ Old Instrument } & \multicolumn{2}{|c|}{ New Instrument } \\
\hline & External & $\begin{array}{l}\text { Domestic } \\
\text { Non-NIS }\end{array}$ & $\begin{array}{l}\text { Domestic, } \\
\text { NIS }\end{array}$ & $\begin{array}{c}\text { External / Domestic, } \\
\text { Non-NIS }\end{array}$ & Domestic \\
\hline US\$ or EC\$ denominated & US\$ & EC\$ & $\mathrm{EC} \$$ & US\$ / EC\$ & $\mathrm{EC} \$$ \\
\hline Instruments & Bonds & Bonds & Bonds & Bonds & Bonds \\
\hline Face value (US\$ mil.) $)^{1)}$ & 193.5 & 34.0 & 34.1 & $143.3(215.2)$ & 37.4 \\
\hline Face-value haircut ${ }^{2)}$ & $50 \%(25 \%)$ & $50 \%(25 \%)$ & $0 \%$ & - & - \\
\hline Maturity & 2025 & 2025 & 2025 & 2030 & 2040 \\
\hline Grace period (years) & 15 & 15 & 15 & 0.5 & 10 \\
\hline Remaining maturity (years) & 10 & 10 & 10 & 15 & 25 \\
\hline Coupon ${ }^{3)}$ & $\begin{array}{l}\text { Step-up } \\
\text { coupon }\end{array}$ & $\begin{array}{l}\text { Step-up } \\
\text { coupon }\end{array}$ & $\begin{array}{l}\text { Step-up } \\
\text { coupon }\end{array}$ & $7 \%$ & $3 \%$ \\
\hline Repayment style & Amortizing & Amortizing & Amortizing & Amortizing & Amortizing \\
\hline Present value in $11 / 2015^{4)}$ & $75 \%$ & $75 \%$ & $75 \%$ & $39 \%$ & $31 \%$ \\
\hline NPV haircut ${ }^{4)}$ 5) & $49 \%$ & $49 \%$ & $59 \%$ & - & - \\
\hline Pre-CACs participation rate $(\%)$ & 94 & 100 & $\mathrm{~N} / \mathrm{A}$ & - & - \\
\hline Post-CACs participation rate (\%) & 100 & - & $\mathrm{N} / \mathrm{A}$ & - & - \\
\hline CACs triggered & Yes & No & $\mathrm{N} / \mathrm{A}$ & - & - \\
\hline
\end{tabular}

1) Face value of new instruments includes capitalized interest arrears on old instruments, with face value of new US\$- and non-NIS EC\$denominated bonds showing both face values after the completion of the IMF-supported program reviews in June 2017 and in November 2015 (in parenthesis).

2) Face-value haircut of US\$- and non-NIS EC\$-denominated bonds shows both face-value haircuts after the completion of the IMF-supported program reviews in June 2017 and in November 2015 (in parentheses).

3) Coupon rates for old instruments: 1 percent until 2008, 2.5 percent until 2011, 4.5 percent until 2013, 6 percent until 2015, 8 percent until 2017, 8.5 percent until 2018 , and 9 percent until maturity.

4) Discount rate of 13.9 percent is used, which was the first transaction-day yield after the completion of the exchange (on 11/18/2015).

5) NPV is defined as (1 - present value of new debt/present value of old debt) (Sturzenegger and Zettelmeyer 2006, 2008). The present values of new debt and old debt are computed with the same discount rate.

Sources: Bloomberg, Grenadian authorities, and authors' calculations.

Both domestic and external private creditors suffered substantial losses in NPV terms (Figure 5). Using a discount rate of 13.9 percent, the NPV haircut was 50.3 percent on average, while the market haircut was 62.5 percent. Both the US\$ and EC\$ 2025 bonds (excluding the EC\$ holdings by the NIS) were treated symmetrically with a NPV haircut of 49.0 percent. In contrast, despite no face-value reductions, domestic NIS holders of the EC $\$ 2025$ experienced a NPV haircut of 58.7 percent. $^{40}$

40 Restructuring agreements were signed on several other domestic debt instruments (including with banks and on T-bills), including NPV haircuts similar to those of the commercial bonds deal. 


\section{Figure 5}

Grenada’s Private Debt Restructuring, 2013-15: NPV Haircuts ${ }^{1)}{ }^{2)}$

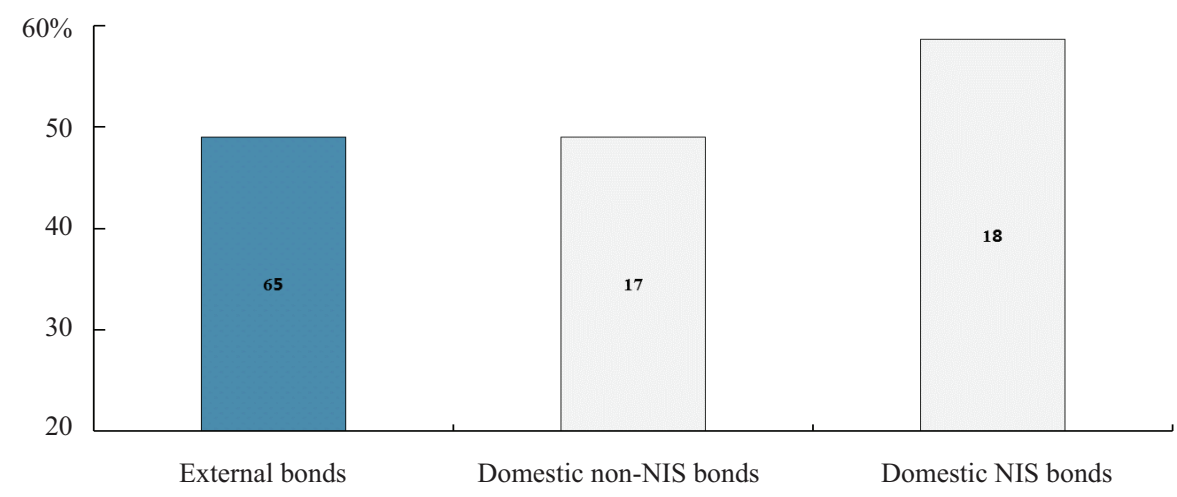

1) Using a discount rate of 13.9 percent, which was the exit yield of EC \$ bonds on November 18, 2015.

2) Figures on bars represent shares of claims in total eligible claims.

Source: Authors' calculations based on Grenadian statistics.

\subsubsection{Official Sector Debt Restructuring}

\subsubsection{Ex-Im Bank of Taiwan Province of China}

On March 4, 2013, The Ex-Im Bank filed a lawsuit in a New York federal court. The filing sought (1) specific performance of the pari passu provision contained in defaulted loans the bank had extended to Grenada and (2) an order preventing payment on outstanding bond debt unless Grenada simultaneously made payments on the defaulted loans. The claim was that Grenada was in violation of the pari passu clause in defaulted loans owed to the Ex-Im Bank. Grenada asked the US District Court to dismiss the suit on grounds that prior litigation precluded raising the pari passu issue for the first time. In May, several bondholders intervened, stating that Grenada's legal arguments were incorrect and that Grenada would prevail on merits based on the facts of the case. In August, the US District Court agreed with these arguments and ordered "discovery" to move forward to a judgment based on specific facts of the case to recover an unpaid judgment worth US\$32 million against Grenada.

On January 7, 2015, the government announced that an agreement had been reached to restructure US\$36.6 million in debt owed to the Ex-Im Bank. The announcement contained the original amounts owed, including arrears and capitalized past interest due. The agreement resulted in a 50 percent nominal principal reduction, with 47 percent reduction taking effect at closing and 3 percent upon the successful conclusion of the IMF-supported program in 2017. Under the terms of the agreement, the post-haircut balance on the loan will be repayable over 15 years - which includes a grace period of three and a half years - at an interest rate of 7 percent. The agreement also included a hurricane clause (Appendix 1), which would allow Grenada to defer payments for a predetermined period should a natural disaster compromise the government's ability to service debt in a timely manner in the future. The restructuring resulted in a NPV haircut of 62 percent and a decline in the public debt stock of 1.8 percent of GDP. In addition, the Ex-Im Bank withdrew its court case, putting an end to the lawsuit against the Grenadian government on the basis of the pari passu contractual clause included in the loan agreement. The withdrawal had a significant impact on the debt restructuring with other creditors, as the pari passu clause would have prevented payments to other creditors until full payment to the Ex-Im Bank was made. 


\subsubsection{Paris Club}

On November 19, 2015, the Paris Club agreed to a debt rescheduling of US\$7.7 million. ${ }^{41}$ This comprised (1) the treatment of arrears as of October 31, 2015 (US\$5.7 million), and (2) the treatment of maturities falling due (US\$ 2.0 million) from November 1, 2015, to June 30, 2017 (when the IMF's Extended Credit Facility is expected to end). The total claims by the Paris Club equaled US\$11 million as of November 1, 2015. The difference between US\$11 million and US\$7.7 million comprises maturities due after 2017.

The treatment under Classic terms consisted of the following:

(1) Repayment of non-ODA credits over 15 years, with an eight-year grace period;

(2) Repayment of ODA credits over 20 years, with a seven-year grace period.

Similar to the previous experience of the debt restructuring in 2004-06, losses to official sector creditors are substantially lower than those to private creditors. NPV haircuts on official loans are estimated to be 3.2 percent using a discount rate of 2.8 percent, which is the market rate prevailing at the time of the exchange (OECD Commercial Interest Reference Rate). ${ }^{42}$ As in the previous official debt restructuring in May 2006, there is no principal reduction. ${ }^{43}$

The Paris Club deal also included a hurricane clause (Appendix 1). This is the first time Paris Club creditors agreed to such a provision. The clause provides the opportunity for creditors "to consider" further debt relief, such as a deferral of debt service in the event of a natural disaster based on an independent assessment of damage and "imminent default." The benefit is that it allows for "consideration" of cash flow relief. However, neither automaticty nor specifics were provided in the Agreed Minute, for example, about the independent assessment of a qualifying disaster, or who or how an assessment of "imminent default" would be made. When compared to the hurricane clause in the private creditor or Ex-Im Bank deal, which provides automatic deferral of debt service for two periods of debt service following a qualifying hurricane, the hurricane clause in the Paris Club agreement is relatively weak.

\subsection{IMF Engagement}

Following the general elections in 2013, the new government started discussions with the IMF on a potential IMF-supported program. The New National Party came to power in February 2013 after a sweeping win during the elections. Strong parliamentary support, following the victory, later proved critical for enabling the government to pursue and implement difficult yet important fiscal consolidation and structural reforms. The new administration subsequently declared default and announced its intention for a comprehensive restructuring of the country's public debt in March 2013. Soon after, discussions started on a potential IMF arrangement to support the authorities' Home Grown Structural Adjustment Program (HGSAP).

A staff-level agreement was reached in March 2014, followed by the Board approval of a three-year ECF-supported program in June 2014. After nearly 12 months of discussions and three negotiating missions (and a technical staff meeting during the IMF Annual Meetings in fall 2013), the authorities and the IMF staff finally reached agreement on the program parameters and the importance of restoring fiscal substantiality while creating supportive conditions for highquality growth. In this respect, the ECF arrangement was aimed at endorsing and supporting the authorities' comprehensive policy agenda under their HGSAP, which sought to (1) enhance competitiveness to promote private sector growth and employment through the implementation of structural reform; (2) secure fiscal and debt sustainability through fiscal adjustment, fiscal

\footnotetext{
41 Paris Club (2015).

42 IMF (2015). The 2 percent coupon rate on ODA loans is based on a simple average of concessional terms provided by Paris Club creditors to a sample of HIPC debt restructuring episodes. The coupon rate on non-ODA loans is assumed to be market based and is calculated as the six-month average of the Commercial Interest Reference rates (CIRR) as published by the OECD.

43 As of July 2017, the Grenadian authorities were still in restructuring discussions with their non-Paris Club bilateral creditors.
} 
legislative reforms, and debt restructuring, while protecting social safety nets; and (3) strengthen financial sector stability by enhancing regulation and supervision. A local Homegrown Programme Monitoring Committee was established with representatives from unions, churches, the private sector, and civil society and put in charge of holding the government accountable for its program and policy commitments.

The design of the IMF program envisaged ambitious fiscal adjustment, anchored by the regional debt target of 60 percent of GDP. The fiscal consolidation effort contemplated under the authorities' HGSAP totaled 71/2 percent of GDP over three years, 2014-16, and was balanced between revenue and expenditure measures. To quickly turn around the fiscal position, the programmed adjustment was frontloaded. However, despite the significant fiscal consolidation, a complementary debt restructuring was deemed necessary to restore long-term debt sustainability by putting public debt on a firmly downward path toward achieving the regional target by 2020 . This would indeed be a notable achievement.

To fortify the fiscal adjustment effort, the program also envisaged a comprehensive structural reform agenda. These important reforms were supported by technical assistance (TA) from Grenada's development partners, including the IMF (from headquarters and the regional TA office in Barbados [CARTAC]), and the World Bank, and were monitored by structural conditionality (benchmarks) under the program. These conditions were aimed at strengthening the country's long-term fiscal prudence with a rules-based legislated fiscal policy framework, public financial management improvements, a broadened tax base, limits to leakage through improved revenue administration, and leveling the playing field for investors through a transparent and rules-based tax incentives system.

Priority was also given to strengthening Grenada's public debt management to avoid a repeat of the debt crisis. In the context of the financing assurance assessments mandated for the program, the IMF team worked closely with the Debt Management Unit (DMU) and its independent financial advisor in debt sustainability analysis and medium-term financing and cash flow forecasts. The IMF team also maintained close contact with the financial advisor for the country's restructuring negotiations to ensure consistency in financing assumptions and to confirm that the restructuring terms were in line with authorities' program parameters. Meanwhile, a considerable amount of technical assistance was provided by the IMF, WB and the Canada Eastern Caribbean Debt Management Advisory Service (CANEC DMAS) Project in strengthening the legislative framework for public debt management and the capacity of the DMU. ${ }^{44}$ Grenada approved a Medium-Term Debt Management Strategy in 2016, with the support of the IMF and WB TA missions.

The authorities also agreed with the IMF team on the importance of prudent management of the Citizenship-by-Investment (CBI) receipts. The authorities revived Grenada's CBI program in 2013, which had been suspended since 2001, in the hope of boosting government revenues and promoting private sector investments. The CBI program offers two options: (1) a donation to the National Transformation Fund (NTF, a special account under the government's Consolidated Fund), and (2) an investment in approved projects along with a fee paid to the government (IMF, 2014b). ${ }^{45}$ The NTF and the government fees are essentially public resources that require prudent and transparent management in a sustainable manner to avoid negative impacts on the government's fiscal position. In this respect, the authorities passed the regulations for NTF, which stipulate that the public sources should be prioritized for debt reduction and contingency savings (for example, to build resilience to natural disasters) and refrain from funding recurrent government expenditure.

\footnotetext{
44 The CANEC DMAS Project is a Canadian International Development Agency (CIDA) funded debt management project, which commenced operations at the Eastern Caribbean Central Bank (ECCB) in 2009.

45 See IMF (2014b) Annex II for details.
} 


\subsection{Outcomes}

The debt restructurings provided a significant reduction in debt service and put the public debt dynamic onto what seems to be a sustainable trajectory. Owing to sizable face-value reductions (50 percent in two steps for the US\$ and non-NIS EC\$ 2025 bonds), debt service was reduced drastically over the medium term, particularly from 2021 onward, when the old instruments were scheduled to be amortized and coupon rates would have been at their highest step-up level (Figure 6). However, because of the short grace period, the new 2030 bonds have comparable debt service obligations with the old 2025 bonds in the near term. Significant near-term cash flow relief in turn is provided by the exchange of the EC $\$ 2025$ bond held by the NIS, and by the restructurings with the Ex-Im Bank and Paris Club. The combined cash flow relief provided by the private creditors over the period 2016-20 totaled US\$8 million. Together with a total fiscal adjustment of more than $8 \frac{1}{2}$ percent of GDP over the three years of the ECF-supported program, the savings from these restructurings (stock reductions from face-value cuts and cash flow reliefs from interest rate reductions) are expected to contribute to reducing Grenada's public debt to 85 percent of GDP by end-2016, and to below 60 percent of GDP by 2020 (IMF 2016b). This will be a notable achievement and departure from Grenada's track record.

\section{Figure 6}

Grenada's Private Debt Restructuring, 2013-15: Debt Service of External Old Instruments and Exchanged Instruments (in millions of US dollars)

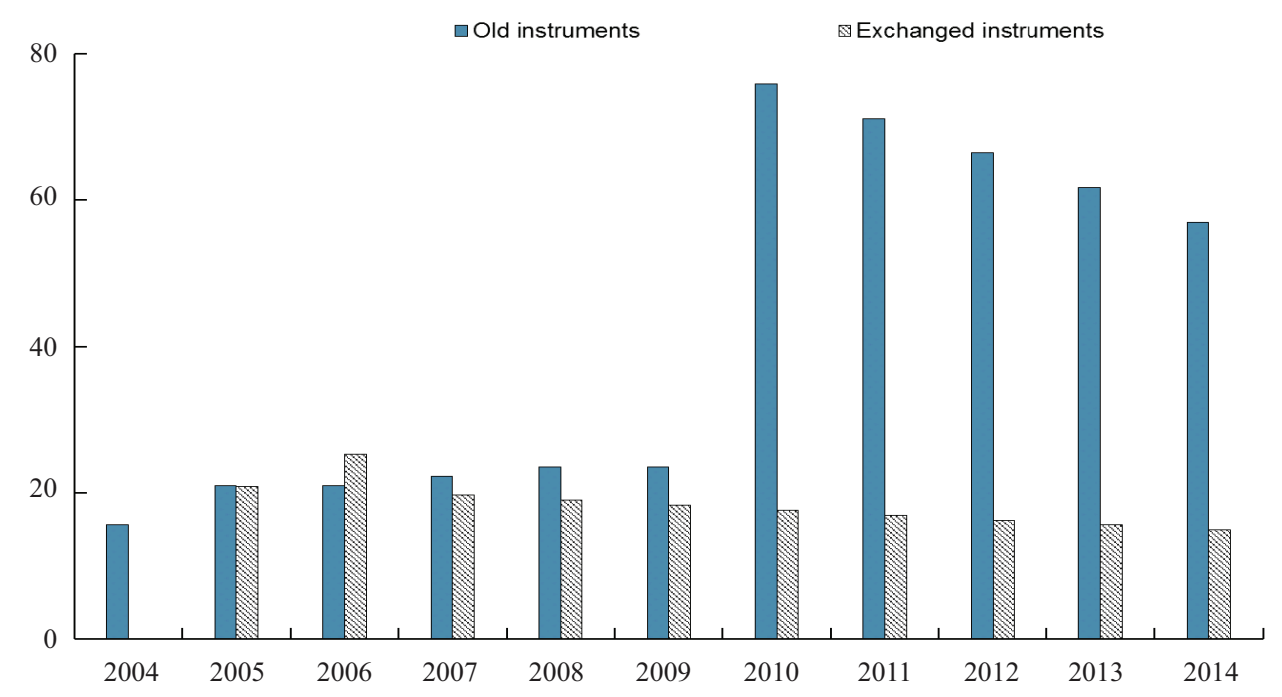

Source: Grenadian authorities and authors' calculations.

As of January 2017, on private external debt, Grenada had not yet had a reassignment of its credit ratings or had not issued in the international market. The credit ratings on Grenada's local currency and foreign currency debt remain NR, as assigned by S\&P in October 2014. Prior to reallocation to NR rating, S\&P had assigned SD to Grenada since March 2013, when coupon payments were missed. Nevertheless, the bond price has recovered from 27 (pre-restructuring) to 55-60 cents on the dollar (Figure 7). However, Grenada has not yet returned to the international market for new financing, partly because the financing needs have been reduced by fiscal surpluses achieved during the adjustment program. On external debt to non-Paris Club creditors, Grenada still has some debt that has not been restructured. ${ }^{46}$

46 Grenada was classified as "debt distress" by IMF DSA (IMF, 2016a) due to the non-completion of all debt restructuring steps and the clearance of arrears to all official creditors. 
Figure 7

Grenada's Private Debt Restructuring, 2013-15: Bond Prices and Credit Ratings

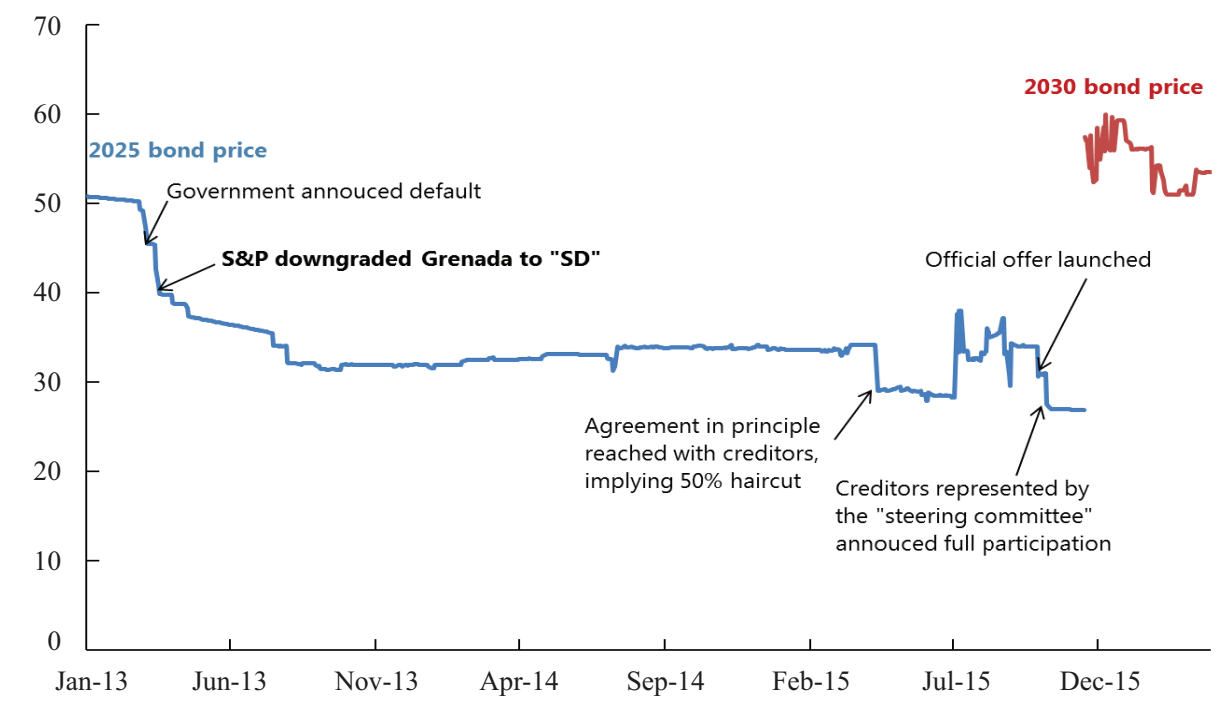

Source: Bloomberg and S\&P.

\subsubsection{Post-Restructuring Debt Redemption Profile}

Guided by the government's new Medium-Term Debt Management Strategy, an effort was made in the 2013-15 restructuring to improve the post-restructuring redemption profile. The 2013-15 debt restructuring significantly reduced the refinancing risk of the government debt portfolio, due to (1) a sizable face-value haircut on its commercial debt (the original 2025 EC\$ and US\$ bonds) and loans from the Ex-Im Bank, which reduced the principal repayments over the medium term, and (2) significant lengthening of maturities of its domestic debt (Figure A1 in Appendix 2).

However, refinancing risk could rapidly increase unless the government takes active steps to lengthen the average maturity of its domestic debt. Further, interest rates on 12 percent of the total debt portfolio would reset within the next year. Unless the practice of issuing only T-bills in the domestic and regional market was discontinued, interest rate risk would again increase, as maturing debt would be refinanced at new interest rates, which would remain uncertain. Future variable-rate debt from multilateral institutions could also increase interest rate risk in an environment of rising global interest rates. Despite a high share (about 60 percent) of the total debt portfolio being denominated in foreign currency, the exchange rate risk was expected to be moderate, as the exchange rate peg had been maintained since 1976. Devaluation was considered a low-probability event with large impacts, hence the risk to the debt portfolio could not be entirely ignored and reliance on external borrowing should gradually have been reduced.

\section{COMPARISON OF KEY ELEMENTS BETWEEN GRENADA'S 2004-06 RESTRUCTURING AND 2013-15 RESTRUCTURING}

From our analysis of the restructuring events in sequence, we now proceed one step further to explore key elements in the 2004-06 and 2013-15 restructuring episodes. ${ }^{47}$ Sections 3 and 4 analyze Grenada's 2004-06 and 2013-15 in chronological order and shed light on causes, processes, IMF-supported programs, and outcomes for each restructuring. This section complements our discussion by contrasting key elements in the two restructurings, in particular

47 Appendix III compares Grenada's experience with other debt restructuring episodes in the Caribbean. 
with regard to (1) cash flow relief; (2) debt sustainability implications; (3) fiscal consolidation; and (4) financing during the debt restructurings.

Figure 4

Comparison between 2004-06 and 2013-15 Private Debt Restructurings

\begin{tabular}{lcc}
\hline \hline & $2004-06$ & $2013-15$ \\
\hline Domestic or external & Domestic / External & Domestic / External \\
Face-value haircut & $0 \%$ & $50 \%(0 \%)$ \\
NPV haircut & $38 \%$ & $50 \%$ \\
Maturity extension (years) & 11.7 & $5(10)$ \\
CACs triggered & No & Yes \\
\hline \hline
\end{tabular}

Sources: Authors' calculations based on Grenadian statistics.

\subsection{Cash Flow Relief}

The 2004-06 restructuring achieved a large frontloaded cash flow relief and substantial maturity extenion. ${ }^{48}$ The 2004-06 private debt restructuring provided US\$93 million in cash flow relief over the first five years compared to the original obligations existing prior to the restructuring. In contrast, the cash flow relief obtained over the first five years following the 2013-15 debt restructuring was only US\$8 million, while the bond exchange achieved a large face-value haircut. The average time to maturity of the 2004-06 restructured debt was 18 years, and the weighted average coupon rate was 6 percent, whereas for the 2013-15 restructuring, the average time to maturity was only eight years and the coupon rate was a flat 7 percent.

Table 5

Cash Flow Relief from the 2004-06 and 2013-15 Debt Restructurings of the US\$ and EC\$ Commercial Bonds (in US\$ million)

\begin{tabular}{lrrrrrrrrrr}
\hline \hline Debt Restructuring & 1 & 2 & 3 & 4 & 5 & 6 & 7 & 8 & 9 & 10 \\
\hline $2004-06$ & 22.0 & 21.9 & 21.7 & 17.7 & 10.4 & 10.4 & 124.1 & 1.5 & 46.7 & -4.5 \\
$2013-15$ & 0.1 & -4.4 & 2.6 & 4.5 & 5.2 & 58.2 & 54.2 & 50.2 & 46.1 & 42.1 \\
\hline \hline
\end{tabular}

Note: Cash-flow relief is calculated as the difference between the principal and interest payments for the original and the restructured debt obligations.

Sources: Authors' calculations based on Grenadian statistics

\subsection{Debt Sustainability Implications of the Debt Restructurings}

Cash flow relief without a nominal principal reduction can restore debt sustainability under limited circumstances. The only way a debt restructuring without a nominal principal reduction could contribute to restoring sustainability is if the future rate of real economic growth were higher than the real rate of interest. This in turn leaves the assessment highly sensitive to the robustness of the growth and interest rate assumptions. In principle, debt restructurings should be

48 It could be noted that while 'NPV loss' calculations provide an indication of investor losses, they do not necessarily offer a good summary of the solvency relief acquired by a sovereign. Hence a given NPV haircut could be achieved with substantial cash flow/liquidity relief but little solvency relief, as in the first restructuring, or with major solvency relief but less impact on immediate cash flows (the second restructuring). If faced with a choice, political economy considerations may encourage a sovereign facing substantial near-term financing needs (as in Grenada 2004-06) to opt for liquidity relief, when a more prudent analysis would recognize that a solvency operation is required. In this context, the 'back loaded' nature of fiscal adjustment following the 2004-06 restructuring was considered problematic. However, the paper does not look whether a 'frontloaded' adjustment would have been feasible in the immediate aftermath of Hurricane Ivan. 
designed in such a way that they are reasonably robust to key economic and financial assumptions. When optimistic assumptions about future prospects are made, and the outturn results indicate a significant downside deviation, the country could return to an unsustainable position. The analysis below examines the debt sustainability implications of the two debt restructurings. ${ }^{49}$

Simulated debt trajectories suggest that the first restructuring was not robust to growth and fiscal policy assumptions (Asonuma et al. 2017c). It is assumed that, at the start, debt is valued at 100 , and the denominator representing the capacity to repay, that is, GDP, is also $100 .^{50}$ The nominal debt trajectories are based on the terms of the debt restructurings as described in the previous sections (Tables 1 and 3 ). To ensure comparability between debt structures, any principal repayments and interest payments for the 2025 and 2030 bonds are assumed to be financed and added back to the stock of debt, using three alternative financing cost assumptions $(2,5$, and 7 percent). Using the debt trajectory in the numerator under alternative refinancing rate assumptions and a GDP index based on the various GDP growth projections and outcomes $(-0.6,2.5$, and 5 percent $)$, the debt trajectories are generated for the 10 years immediately after the debt restructurings. In 2005, annual GDP growth was projected at 4.5 percent over the medium term, compared to the 10-year historical average of 3.2 percent. However, with a realized average growth rate of -0.6 percent during 2005-15, a rate significantly lower than the real effective interest rate on government debt, the public debt ratio explodes after the restructuring despite the large NPV haircut. ${ }^{51}$

In contrast, the 2013-15 debt restructuring involving principal reduction is expected to result in a more durable and sustainable debt position. Simulations show that the debt trajectory remains below its original level under all assumptions except for an extreme adverse growth shock (averaged at -0.6 percent) combined with high financing costs (at 7 percent). Although the debt ratio is still projected to rise (after the two-step haircut) when the growth rate falls below the refinancing interest rate and will rise more rapidly when the differential is larger, the upfront stock reduction through principal haircut provides a comfortable cushion to absorb these potential setbacks.

Simulation results also suggest that a maturity extension and a step-up coupon structure have beneficial effects only under limited conditions. In particular, if the problem facing the government is liquidity shortage, maturity extension and step-up coupons with initially belowmarket interest rates could provide the government with breathing space to implement fiscal consolidation and restore market confidence, while implementing structural reforms that would transform the economic structure to generate and sustain higher economic growth. However, if GDP growth is not higher than the weighted average implied interest rate on the restructured (step-up coupon) debt, the debt ratio will increase.

\subsection{Fiscal Consolidation and Debt Sustainability}

The phasing of fiscal adjustment mattered. With regard to medium-term fiscal adjustment by the authorities, the adjustment path was backloaded during and following the 2004-06 restructuring, whereas it was frontloaded during and following the 2013-15 restructuring. The authorities' 2006 IMF-supported program aimed at a 4⿳亠丷厂 percentage points of GDP improvement in the primary balance (excluding grants) to be "phased-in through 2008 — consistent with the need to avoid fiscal retrenchment becoming a drag on the recovery and accommodate the large capital spending needs in 2006 and 2007 to rehabilitate public infrastructure and buildings." With a $2 \frac{1}{2}$

\footnotetext{
To facilitate the analysis, comparison is made only for the EC\$ and US\$ 2025 bonds and the 2030 bonds
}

50 In this exercise, the starting point for the first restructuring is 2005 and that for the second restructuring is 2015 . The debt ratio created is a hypothetical index with a starting point of 1 . It extracts from the primary balance, additional interest and principal repayments arising from other existing and new debt. The actual DSA is discussed in the next section.

51 The refinancing rate makes little difference to the debt ratio for the 2005 debt restructuring because, by construction, the cash flows in the earlier period are limited. 
percent primary surplus target thereafter and long-term growth of 4 percent, the projection was that this would enable the debt-to-GDP ratio to decline to 60 percent by 2015 . Instead, the actual outturn was an average primary deficit of 3 percent of GDP between 2006 and 2012, resulting in a debt-to-GDP ratio of 110 percent at end-2013. In contrast, the 2014 IMF-supported program envisioned a fiscal consolidation of $73 / 4$ percent points of GDP targeted over three years, with three quarters of the effort to be undertaken in the first two years of the program. This adjustment would bring the debt-to-GDP ratio to 89 percent by 2020, which would then be complemented by a comprehensive debt restructuring to achieve the 60 percent regional debt-to-GDP target.

\subsection{Financing during the Debt Restructurings}

To continue their operations during debt restructuring, governments require some form of continuous financing. During a debt restructuring, burden sharing often takes the form of (1) new credit from some creditors who are not subject to the restructuring; (2) accumulation of arrears to suppliers and creditors; or (3) raising revenues and reducing nonessential expenditures to generate primary surpluses. With an IMF-supported program in place, other multilateral institutions and official bilateral creditors may provide fresh credit to support the government to achieve macroeconomic stabilization, fill the financing gap, and restore debt sustainability. Under an IMF-supported program, new arrears to suppliers are generally not allowed, while the IMF is willing to tolerate arrears to private creditors only when prompt support is considered essential for the successful implementation of the member's adjustment program; and the member is pursuing appropriate policies and is making a good faith effort to reach a collaborative agreement with its creditors. ${ }^{52}$ Domestic T-bills also often play a role in filling the financing gap during a restructuring.

During both debt restructurings of Grenada, multilateral institutions and bilateral official creditors provided fresh credit to support the authorities. During 2004-06, multilateral institutions provided US $\$ 15$ million in net new credit, two thirds of which was from the CDB, to support the government in its reconstruction efforts in the aftermath of Hurricane Ivan. The IMF-supported program that started after the completion of the debt exchange provided Grenada with additional SDR10.5 million in support of its economic and financial policies. Also, bilateral creditors provided US $\$ 20$ million in net new loans, with over half being financed by the government of Trinidad and Tobago, and Belgium providing a good part of the remainder. During the period of 2013-15, the World Bank, the CDB, and the IMF provided US\$57 million in new credit. Bilateral credit, on the other hand, experienced a net repayment, as the government had entered into an arrears clearance agreement with the government of Kuwait ahead of the restructuring. However, the Kuwait Fund, the OPEC Fund, Trinidad and Tobago, and Venezuela provided new credit in 2012, prior to the announcement of the debt restructuring. Since the government was likely to refrain from future external market access for some time after the debt restructuring, continued reliance on multilateral and bilateral creditors was expected.

T-bills played a critical role during the debt restructuring of 2013-15 but not during 2004-06 (Table 6). The last 91-day T-bill issued on the RGSM was in November 2003, and was not rolled over when it matured in February 2004. A 365-day T-bill was issued in July 2004, before Hurricane Ivan hit in September and before the October announcement of the restructuring. This 365-day T-bill was rolled over in July 2005 and in subsequent years. In effect, there was zero net financing from T-bills during the 2004-06 debt restructuring period. In contrast, net financing through the 91-day and 365-day T-bills issued on the RGSM remained robust during the 2013-15 period, with a cumulative net financing of EC\$29 million and EC\$12 million, respectively, or a cumulative total T-bills contribution of EC $\$ 41$ million.

52 IMF Lending into Arrears Policy. 
Table 6

Treasury Bill Issuances and Redemptions on the Regional Government Securities Market (in millions of East Caribbean dollars)

\begin{tabular}{lrrrrrrrrrrrrr}
\hline \hline & 2003 & 2004 & 2005 & 2006 & 2007 & 2008 & 2009 & 2010 & 2011 & 2012 & 2013 & 2014 & 2015 \\
\hline 91-day T-bills & & & & & & & & & & & & & \\
New issuance & 15 & 0 & 0 & 0 & 0 & 0 & 0 & 0 & 34 & 24 & 39 & 59 & 54 \\
Redemption & 0 & -15 & 0 & 0 & 0 & 0 & 0 & 0 & 0 & -34 & -24 & -39 & -59 \\
Net issuance & 15 & -15 & 0 & 0 & 0 & 0 & 0 & 0 & 0 & -10 & 15 & 19 & -5 \\
365-day T-bills & & & & & & & & & & & & & \\
New issuance & 0 & 24 & 21 & 23 & 34 & 35 & 46 & 55 & 56 & 47 & 49 & 56 & 58 \\
Redemption & 0 & 0 & -24 & -21 & -23 & -34 & -35 & -46 & -55 & -56 & -47 & -49 & -56 \\
Net issuance & 0 & 24 & -3 & 2 & 11 & 0 & 12 & 8 & 1 & -9 & 3 & 7 & 2 \\
Total T-bills & & & & & & & & & & & & & \\
New issuance & 15 & 24 & 21 & 23 & 34 & 35 & 46 & 55 & 90 & 71 & 89 & 115 & 112 \\
Redemption & 0 & -15 & -24 & -21 & -23 & -34 & -35 & -46 & -55 & -90 & -71 & -89 & -115 \\
Net issuance & 15 & 9 & -3 & 2 & 11 & 0 & 12 & 8 & 35 & -19 & 18 & 26 & -3 \\
\hline \hline
\end{tabular}

Sources: Authors' calculations based on Grenadian statistics.

\section{LESSONS LEARNED}

While our analysis focuses on two restructuring episodes in one country, Grenada, driven predominantly by country-specific facors, we can draw lessons for consideration in future debt restructurings. ${ }^{53}$ Grenada's debt restructuring experience suggests the importance of establishing clear objectives and a clear perimeter for the claims eligible for a debt restructuring; commitment and ownship of the policy and structural reforms; and close engagement and clear communication with creditors. Nevertheless, we acknowledge that case-specific outcomes will need to take into account the country-specific external and internal constraints, and the complex nature of debt restructuring negotiations.

\section{- 1. Setting appropriate objectives}

The government needs to set out appropriate objectives which regard to what it expects to achieve from a debt restructuring. In particular, it should present its views on whether there is a liquidity or a solvency problem and the underlying cause of the problem (Appendix 3). During the 2004-06 restructuring episode, the fiscal crisis faced by Grenada was perceived by the authorities as more of a liquidity problem, which led to the eventual outcome of a more frontloaded cash flow relief with limited debt stock reduction as compared to the 2013-15 debt restructuring.

\section{- 2. Setting a clear perimeter for the debt under restructuring and renegotiation}

Experience shows that clarity with respect to the perimeter of the debt restructuring is essential for an efficient resolution. The government needs to make clear which part of its debt will be subject to debt restructuring, casting as wide a perimeter as possible to promote evenhandedness, while avoiding cutting off new sources of financing needed to fund day-to-day operations of the

53 See IMF (2013) for more general lessons and IMF (2014c, 2015c, 2015d) for concrete proposals. Moreover, see also Brookings-CIEPR (2013) and Erce (2013) for further policy discussions. 
government. Whereas the Grenada 2004 debt-restructuring announcement was not clear about the debt subject to "cooperation of its creditors," the 2013 announcement was clear about coverage. It conveyed the government's intent to seek collaborative and comprehensive debt restructuring, explicitly excluding debt to multilateral institutions and T-bills issued in the RGSM-accounting for about 30 percent of public debt in 2013. T-bills issued on the RGSM were excluded from the restructuring, as that would have had broader implications for the regional market. Credit from international financial institutions (IFIs) was also excluded, and this enabled the IFIs to provide new credit to the government while it implemented reforms and negotiated debt restructuring.

\section{- 3. Taking policy and reform actions to anchor policy credibility and strengthen fiscal prudence and growth prospects}

Fair burden sharing between a sovereign debtor and creditors, as well as among creditors, is important in facilitating an effective voluntary debt restructuring agreement. Creditors tend to agree to a debt restructuring only if the government lays out a comprehensible and credible set of measures to restore imbalances that have led to a situation requiring a debt restructuring. In particular, fiscal measures that reduce expenditures and strengthen revenue collection, while protecting the vulnerable sectors, and measures that enhance external competitiveness and promote growth, including structural measures, are considered key factors to achieve and sustain the necessary adjustments. The latter is particularly important for long-term creditors who are expected to continue investing in the country beyond the short and medium terms. Strong ownership of economic policies by the government against risks of economic contractions and exogenous shocks is critical in securing the support of creditors and international development partners.

The IMF can play a pivotal role as an independent assessor of the economic health of the country, providing views on reform actions needed to restore investor confidence and economic growth, market access, and debt sustainability. This can be done in the context of the annual Article IV surveillance. However, an IMF-supported program cannot proceed if the Fund assesses that debt is not sustainable under existing policies. In such cases, the authorities may determine that they need to undertake a debt restructuring in order to achieve sustainability objectives, subject to IMF policies. ${ }^{54}$ The IMF will develop with the authorities the appropriate fiscal adjustment path, as well as the structural reform measures needed to ensure that risks to future debt sustainability are reduced, thus providing a credible anchor for creditors to base their decisions. The 2004-06 debt restructuring was completed before the IMF-supported program began, while the 2013-15 debt restructuring took place within the context of an IMF-supported program. In the 2013-15 debt restructuring, creditors anchored the second nominal principal reduction to the successful completion of the IMF-supported program, ensuring incentive compatibility of a successful completion of the program with the reward given as a debt restructuring by private creditors. Other IFIs that provide fresh credit during a debt restructuring may also set conditions requiring the government to implement reforms that address risks to debt sustainability and promote growth.

\section{- 4. Designing robust debt restructuring scenarios and legal clauses}

To ensure a durable exit from an unsustainable debt situation, the authorities should present robust restructuring scenarios and simulations. When developing alternative debt restructuring scenarios, it would be useful to conduct scenario analysis by varying future borrowing costs to refinance debt service obligations, as well as growth assumptions. ${ }^{55}$ Hence, step-up coupons may appear attractive at the beginning, but unless economic growth is higher than the coupon rates, the debt level will rise again as soon as the relationship is reversed. This will ensure that the restructuring will have material impact on future debt sustainability. In this respect, early realization of the need

\footnotetext{
54 The relevant policies that come into play include: non-toleration of arrears to official creditors, lending into arrears to private creditors, financing assurances, and public debt limits in IMF-supported programs.

55 The IMF DSA could be used as a means of producing and examining such scenarios.
} 
for a principal reduction could lessen the possibility of a future restructuring. Professional debt advisors are typically used to strengthen countries' negotiating position.

In both of Grenada's restructuring episodes, the authorities, in consultation with their financial advisors, prepared several restructuring scenarios, which they shared with creditors during negotiations. In addition, there could be downside risk to fiscal projections and exogenous shocks, including natural disaster shocks - thus the introduction of the hurricane clause in the exchanged bonds of Grenada in 2015. In the case of the country's 2013-15 restructuring, the analysis was abstracted from possible exchange rate risk, but robustness to exchange rate shocks should also be assessed.

\section{- 5. Engaging creditors in close and effective communication}

Effective communication of the government's economic policy and strategy is crucial to the success of a debt restructuring. During the 2013-15 restructuring, the Grenada authorities explained clearly to bondholders the economic situation and options available, along with the cost of each option. The credible economic program they proposed provided a framework for debt restructuring negotiations and helped build creditor confidence as debt sustainability was restored.

Maintaining good contact and sharing of relevant data with creditors is also important in maintaining constructive discussions. Continuous engagement with creditor groups, providing the information that includes recent updates on economic conditions and policies implemented, could help lead to an efficient resolution. Further, to support the case for a debt restructuring, the government needs to provide relevant data about, for example, the fiscal accounts and balance of payments, along with financing assumptions. This will enable creditors to independently assess the country's debt sustainability situation. To the extent possible, this should be provided on the government's website to ensure equal treatment of creditors. However, some assumptions might need to be shared under a nondisclosure agreement. The authorities maintained close relations with creditors in both of Grenada's restructurings, and shared information relevant to DSA in the second restructuring. ${ }^{56}$

The financial and legal advisors are typically external experts who communicate with creditors with, or on behalf of, the government. They help the government: (1) gather the necessary information and make it available to creditors, and (2) analyze the information and propose alternative debt restructuring strategies, as was mentioned above in the case of Grenada's restructurings.

\section{CONCLUSION}

Sovereign debt restructurings are undertaken to provide cash flow relief and/or help restore debt sustainability. Grenada's two restructurings discussed in this paper are not exceptions. Both the 2004-06 and 2013-15 debt crises and restructurings were the consequence of debt service payments and elevated public debt levels that were not sustainable caused by excessively expansionary fiscal policies. The crises in each case were triggered or exacerbated by large external shocks. The IMF is unable to lend to a sovereign when, under the most realistic and sophisticated assumptions and projections for growth and financing, the level of debt is deemed unsustainable. In such cases, a sovereign may choose to undergo a debt restructuring to achieve sustainability.

The main lesson from Grenada's 2004-06 restructuring is that, while effective in providing liquidity, it did not provide enough buffer to safeguard debt sustainability. Two years after the restructuring, the public debt ratio began to shoot up while the country faced adverse shocks from

56 See http://www.gov.gd/debt_restructuring.html. 
the global financial crisis. An optimistic growth assumption had led to the belief that the country would eventually grow its way out of the debt crisis. In hindsight, the impact of potential adverse shocks on debt dynamics, the failure to recognize and resolve the underlying macro imbalances and unsustainable debt outlook facing the country eventually led Grenada to another restructuring just 10 years later.

Grenada drew on many of the lessons from the previous experience. The 2013-15 debt restructuring targeted and achieved substantial outright principal reductions through the debt exchange. These principal reductions would directly reduce Grenada's public sector debt by more than 10 percent of GDP and indirectly lower debt service payments going forward. Strong ownership by the government of its structural adjustment program, particularly its decisive actions in correcting fiscal imbalances and strengthening the fiscal policy framework, helped put public finances on a sustainable path and the economy on track to regain investor confidence and build resilience to external shocks. Time will tell if the debt relief and restructuring together with the new policy framework that instills fiscal prudence will be enough to preclude it from happening again.

Grenada's 2013-15 restructuring also brought a new perspective to the sovereign debt restructuring framework with the important innovations discussed. To review, the special features in the 2013-15 restructuring include: (1) the two-step principal haircuts, with the first half implemented upon exchange and the remaining half contingent on the completion of Grenada's three-year ECF-supported program in 2017; (2) the inclusion of special warrants related to Grenada's Citizenship by Investment (CBI) Program in the new bonds, which entitle bondholders to receive a capped portion of the $\mathrm{CBI}$ revenues that may be generated above certain thresholds following the successful completion of the ECF-supported program; and (3) the inclusion of the hurricane clause in the new bonds, allowing Grenada to capitalize interest and defer principal maturities due on the bonds for a specified period in the event of a qualifying natural disaster.

Finally, fiscal vigilance is again stressed as the main paragon to avoid a repetition of history. Building resilience and policy buffers are especially important for small countries facing frequent external shocks, for example, natural disasters. An early warning exercise could help identify and regularly monitor external vulnerabilities. Further, fiscal policy should aim to be countercyclical and be prudent to avoid spending overruns that risk jeopardizing fiscal and debt sustainability.

\section{Acknowledgements}

This is an extended version of IMF Working Paper "Sovereign Debt Restructurings in Grenada: Causes, Processes, Outcomes, and Lessons Learned" (Asonuma et al. 2017c, WP 17/171). The views expressed in this paper are those of the authors and should not be attributed to the International Monetary Fund, its Executive Boards or its management. The authors would like to thank Trevor Alleyne, Julianne Ams, Tom Best, Xavier Debrun, Mark Joseph Flanagan, Daniel Hardy, Klaus P. Hellwig, Nicole L. Laframboise, Natasha Marquez-Sylvester, and Rafael Molina for helpful comments and suggestions. We would also like to thank Christie Chea, Eneshi Irene Kapijimpanga, Chifundo Moya for helpful editorial suggestions.

\section{References}

Antigua and Barbuda, Debt Management Unit. 2011. Debt Profile Review: 2006 to 2010.

Asonuma, T. 2016. "Serial Svereign Defaults and Debt Restructurings," IMF Working Paper No. 16/66. Washington: International Monetary Fund.

Asonuma, T., M. Chamon, A. Erce, and A. Sasahara. 2018. "Costs of Sovereign Defaults: Restructuring Strategies, Bank Distress, and the Capital Inflow-Investment Channel,” forthcoming as IMF Working Paper. 
Asonuma, T., M. Chamon, and A. Sasahara. 2016. "Trade Costs of Sovereign Debt Restructurings: Does a MarketFriendly Approach Improve the Outcome?” IMF Working Paper No. 16/222. Washington: International Monetary Fund.

Asonuma, T., M.X. Li, M.G. Papaioannou, S. Thomas, and E. Togo, 2017c, "Sovereign Debt Restructurings in Grenada: Causes, Processes, Outcomes, and Lessons Learned," IMF Working Paper 17/171. Washington: International Monetary Fund.

Asonuma, T., D. Niepelt, and R. Ranciere. 2017a. "Sovereign Bond Prices, Haircuts and Maturity," NBER Working Paper No. 23864. Cambridge: National Bureau of Economic Research.

Asonuma, T., and M.G. Papaioannou, 2016. "Domestic Sovereign Debt Restructurings: Processes, Outcomes and Challenges," manuscript, IMF.

Asonuma, T., M.G. Papaioannou, G. Peraza, K. Vitola, and T. Tsuda. 2017b. "Sovereign Debt Restructurings in Belize: Debt Sustainability and Financial Stability Aspects," Journal of Banking and Financial Economics, Vol. 2 (8), 5-26.

Asonuma, T., and H. Joo. 2017. "Sovereign Debt Restructurings: Delay in Renegotiations and Risk Averse Creditors," forthcoming as IMF Working Paper.

Asonuma, T., and C. Trebesch. 2016. "Sovereign Debt Restructurings: Preemptive or Post-Default," Journal of European Economic Association, Vol. 14 (1), 175-214.

Brookings Committee on International Economic Policy and Reform (CEIPR). 2013. "Revisiting Sovereign Bankruptcy.” Brookings Institution. October.

Buchheit, L.C. 2009. "Use of Creditor Committees in Sovereign Debt Workouts," Business Law International, Vol. 10, 205-217.

Buchheit, L.C., and E. Karpinsky, 2006. "Grenada's Innovations," Journal of Banking Law and Regulation, Vol. 20 (4), 227-231.

Catao, L.A.V., A. Fostel, and S. Kapur. 2009. "Persistent Gaps and Default Traps," Journal of Development Economics, Vol. 89 (2), 271-284.

Cruces, J., and C. Trebesch. 2013. "Sovereign Defaults: The Price of Haircuts," American Economic Journal: Macroeconomics, Vol. 5 (3), 85-117.

Das, U., M. Papaioannou, and C. Trebesch. 2012. "Sovereign Debt Restructurings 1950-2010: Literature Survey, Data, and Stylized Facts,” IMF Working Paper No. 12/203. Washington: International Monetary Fund.

Diaz-Cassou, J., A. Erce, and J. Vazquez-Zamora. 2008. "Recent Episodes of Sovereign Debt Restructurings: A CaseStudy Approach,” Banco de Espana Occasional Paper No. 0804. Madrid: Banco de Espana.

Duggar, E. 2013. "The Role of Holdout Creditors and CACs in Sovereign Debt Restructurings," Moody's Sovereign Default Series Compendium, October 7, 2003.

Eichengreen, B., R. Hausmann, and U. Panizza. 2005a. "The Mystery of Original Sin,” in B. Eichengreen and R. Hausmann eds. Other People's Money: Debt Denomination and Financial Instability in Emerging-Market Economies, pp. 233-265. Chicago: University of Chicago Press.

Eichengreen, B., R. Hausmann, and U. Panizza. 2005b. "The Pain of Original Sin," in B. Eichengreen and R. Hausmann eds. Other People's Money: Debt Denomination and Financial Instability in Emerging-Market Economies, pp. 13-47. Chicago: University of Chicago Press.

Erce, A. 2013. "Sovereign Debt Restructurings and the IMF: Implications for Future Official Interventions," Federal Reserve Bank of Dallas Working Paper No. 143. Dallas: Federal Reserve Bank of Dallas.

Finger, H., and M. Mecagni. 2007. "Sovereign Debt Restructuring and Debt Sustainability_An Analysis of Recent Cross-Country Experience," IMF Occasional Paper No. 255. Washington: International Monetary Fund.

Grenada, Ministry of Finance. 2005. Offering Memorandum, September 9, 2005.

Grenada, Ministry of Finance. 2015. Offering Memorandum, October 5, 2015.

International Monetary Fund (IMF). 2004. "Statement of the IMF Mission in Grenada," Press Release No. 04/102. Washington: International Monetary Fund.

International Monetary Fund (IMF). 2005a. "Grenada: 2005 Article IV Consultation,” IMF Staff Report; and "Public Information Notice on the Executive Board Discussion," IMF Country Report No. 05/229. Washington: International Monetary Fund.

International Monetary Fund (IMF). 2005b. "Grenada: Assessment Letter for the International Financial Community." Washington: International Monetary Fund.

International Monetary Fund (IMF). 2006. "Grenada: Request for a Three-Year Arrangement Under the Poverty Reduction and Growth Facility-Staff Report; and Press Release on the Executive Board Discussion," IMF Country Report No. 06/277. Washington: International Monetary Fund.

International Monetary Fund (IMF). 2013. "Sovereign Debt Restructuring-Recent Developments and Implications for the Fund's Legal and Policy Framework," IMF Board Paper, April. Washington: International Monetary Fund. 
International Monetary Fund (IMF). 2014a. "Grenada: 2014 Article Consultation and Request for an Extended Credit Facility Arrangement—Staff Report; and Press Release,” IMF Country Report No. 14/196. Washington: International Monetary Fund.

International Monetary Fund (IMF). 2014b. "Grenada: First Review under the Extended Credit Facility Arrangement and Financing Assurances Review_-Staff Report; and Press Release,” IMF Country Report No. 14/363. Washington: International Monetary Fund.

International Monetary Fund (IMF). 2015. "Reforming the Fund's Policy on Non-Toleration of Arrears to Official Creditors," IMF Board Paper, December. Washington.

International Monetary Fund (IMF). 2016a. "Grenada: Staff Report for the 2016 Article IV Consultation, Fourth Review under the Extended Credit Facility, Request for Waiver of Non-Observance of a Performance Criterion, Request for Modification of a Performance Criterion and Financing Assurances Review-Staff Report; and Press Release,” IMF Country Report No. 16/133. Washington: International Monetary Fund.

International Monetary Fund (IMF). 2016b. "Grenada: Staff Report for the Fifth Review Under the Extended Credit Facility, Request for Modification of Performance Criteria, and Financing Assurances Review,” IMF Country Report No. 16/389. Washington: International Monetary Fund.

Jahan, S. 2013. "Experiences with Sovereign Debt Restructuring: Case Studies from the OECS/ECCU and Beyond," in Schipke, A., A. Cebotari, and N. Thacker, eds. The Eastern Caribbean Economic and Currency Union: Macroeconomic and Financial System. Washington: International Monetary Fund.

Okwuokei, J., and B. Van Selm, 2017, "Debt Restructuring in the Caribbean - the Recent Experience," forthcoming, International Monetary Fund.

Panizza, U., F. Sturzenegger, and J. Zettelmeyer. 2009. "The Economics and Law of Sovereign Debt and Default," Journal of Economic Literature, Vol. 47 (3), 651-698.

Paris Club. 2006. Press Release, http://www.clubdeparis.org/en/traitements/grenada-12-05-2006/en.

Paris Club. 2015. Press Release, http://www.clubdeparis.org/en/traitements/grenada-19-11-2015/en.

Reinhart, C., and K. Rogoff. 2005. "Serial Default and the 'Paradox' of Rich-to-poor Capital Flows," The American Economic Review, Vol. 94 (2), 53-58.

Reinhart, C., and K. Rogoff. 2009. This Time is Different: Eight Centuries of Financial Folly. Princeton: Princeton University Press.

Reinhart, C., K. Rogoff, and M. Savastano. 2003. "Debt Intolerance,” Brookings Papers on Economic Activity, Vol. 1 (Spring), 1-74.

Schipke, A., A. Cebotari, and N. Thacker. 2013. The Eastern Caribbean Economic and Currency Union: Macroeconomic and Financial Systems. Washington: International Monetary Fund.

Sturzenegger, F., and J. Zettelmeyer. 2006. "Debt Defaults and Lessons from a Decade of Crises.” MIT Press.

Sturzenegger, F, and J. Zettelmeyer. 2008. "Haircuts: Estimating Investor Losses in Sovereign Debt Restructuring, 1998-2005," Journal of International Money and Finance, Vol. 27 (5), 780-805.

Tomz, M., and M. Wright. 2013. "Empirical Research on Sovereign Debt and Default," Annual Review of Economics, Vol. 5, 247-272. 


\section{APPENDIX 1.}

\section{Hurricane Clause and Citizenship by Investment Program Revenue Sharing Clause in the Exchange Offer in the 2013-15 Restructuring}

\section{Appendix 1.1. Hurricane Clause ${ }^{57}$}

The hurricane clause included in Grenada's recent sovereign debt bond contracts enables changes to the scheduled debt service payments upon the realization of an exogenous natural disaster event. Since the changes to the scheduled debt service payments are pre-defined in a contract, this reduces the probability that another debt restructuring will be triggered. The hurricane clause is designed to provide cash flow relief at a critical moment after a natural disaster event, when financing needs are greatest and new sources are scarce. Therefore, it enables Grenada to redirect funds intended for debt service to more immediate needs, reducing the economic impact of the natural disaster.

Key features of the hurricane clause include (Table A1):

- Verifiable trigger event measured by an independent entity: Grenada is a member of the Caribbean Catastrophic Risk Insurance Facility (CCRIF) SPC and has purchased insurance against the risks of tropical cyclones, earthquakes, and excess rainfall. The event is triggered based on parametric measures. If the insurance is triggered, as determined by the CCRIF, the hurricane clause in the bond contract is also triggered.

- Changes to the cash flow: The clause provides for deferred payments for up to two payment periods, and there is no nominal principal or interest rate reduction. The deferred interest payment is capitalized and the deferred principal payment is distributed equally on top of the scheduled payments until final maturity.

- Maximum number of triggers: The contract allows the trigger to be invoked for up to three times.

The cash flow relief that may result from the hurricane clause is equivalent to the probable maximum loss of an event that occurs once every 25 years in Grenada. Depending on the timing of the event, a one-off trigger of the hurricane clause could provide a cash flow relief of up to 2.6 percent of GDP. This compares with about 1.5 percent of GDP for the probable maximum loss from an event that occurs once every 25 years in Grenada, and the average annual loss experienced in Grenada of 9.87 percent of GDP. If three events are triggered, the total cash flow relief could be as much as 7.4 percent of GDP. The charts illustrate the scheduled debt service payments and the payments under a scenario where the hurricane clause is triggered at end-2024.

The hurricane clause in a debt contract is inherently a liquidity relief instrument. A debt being a fixed-income instrument, the maximum cash flow relief in a debt contract will be the amount originally due. For a catastrophic event such as Hurricane Ivan, which caused an estimated damage of 200 percent of GDP, the cash flow relief from the hurricane clause cannot be expected to match the potential financing needs. An instrument such as the catastrophe bond or insurance would be more appropriate.

Grenada Ministry of Finance (2015). 
Scheduled Debt Service: 2030 Bonds and Taiwan

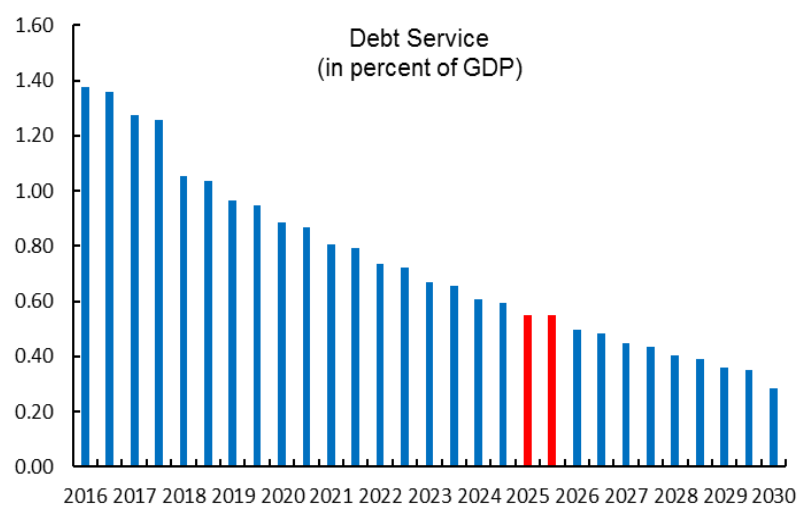

Debt Service after a Hypothetical Call on Hurricane Clause in 2024: 2030 Bonds and Taiwan

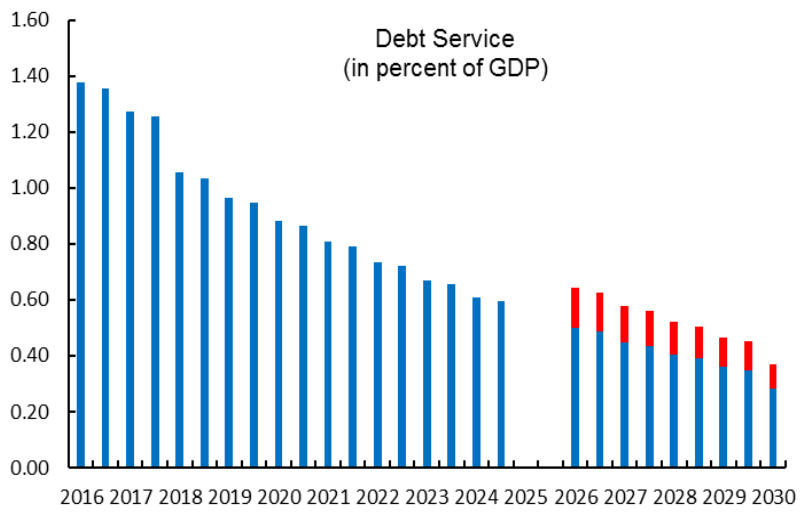

Source: Authors' calculations based on Grenadian statistics.

The hurricane clause defines an "event" as clearly distinct from an "event of default." The clarity of the definition of the natural disaster event in a bond contract ensures that the nonpayment of the scheduled debt service does not trigger an event of default, which could cause S\&P to downgrade the bond to SD.

\section{Appendix A1.2. Citizenship program revenue sharing clause $\mathrm{s}^{58}$}

To sweeten the deal, the exchange offer provides holders of the new 2030 bonds an opportunity to receive a portion of eligible revenues received by Grenada under its Citizenship-by-Investment (CBI) program after the completion of its current program with the IMF. Certain conditions have to be met to trigger the clause, including: (1) the second step haircut has occurred; (2) more than US\$15 million in eligible CBI revenues has been received by Grenada in any given year; and (3) the cumulative limit (NPV of cumulative CBI revenue sharing cannot exceed 35 percent of the face value of the new 2030 bonds) for CBI payment amounts has not been reached.

58 Citizenship-by-Investment programs, which offer citizenships to foreign nationals in exchange for qualified donations or investments, exist in several Caribbean countries, including Antigua and Barbuda, Dominica, Grenada, and St. Kitts and Nevis. Details of the clause can be found in the Offering Circular to exchange Grenada's 2025 bonds (Grenada Ministry of Finance, 2015). 
Table A1

Details of Grenada's Hurricane Clause

\begin{tabular}{|c|c|c|c|}
\hline & Private Bondholders & Taiwan & Paris Club \\
\hline Event & $\begin{array}{l}\text { Hurricane insured under } \\
\text { CCRIF Parametric Insurance } \\
\text { Contract dated June 1, } 2015\end{array}$ & $\begin{array}{l}\text { Hurricane, earthquake, excess } \\
\text { rainfall insured under CCRIF } \\
\text { Parametric Insurance Contract } \\
\text { dated June } 1,2012\end{array}$ & $\begin{array}{l}\text { "Hurricanes" understood } \\
\text { in the wider meaning of the } \\
\text { word (including for example } \\
\text { tropical storm) but causing } \\
\text { serious damage }\end{array}$ \\
\hline Trigger & $\begin{array}{l}\text { CCRIF SPC modelled losses } \\
\text { exceeding US } \$ 15 \text { million }\end{array}$ & $\begin{array}{l}\text { CCRIF SPC modelled losses } \\
\text { exceeding US } \$ 15 \text { million }\end{array}$ & $\begin{array}{l}\text { Assessment to be made on } \\
\text { a case-by-case basis with no } \\
\text { pre-defined set of indicators }\end{array}$ \\
\hline Independent Body & CCRIF SPC & CCRIF SPC & $\begin{array}{l}\text { "Independent assessments" } \\
\text { by IFIs, regional institutions } \\
\text { or any organization that the } \\
\text { PC Creditors, with the help } \\
\text { of the Secretariat, will judge } \\
\text { relevant, including the IMF, } \\
\text { World Bank. CCRIF SPC, } \\
\text { the CDB and the National } \\
\text { Hurricane Center }\end{array}$ \\
\hline Debts Affected & $\begin{array}{l}\text { Principal and accrued interest } \\
\text { due on the deferral dates }\end{array}$ & $\begin{array}{l}\text { Principal and accrued interest } \\
\text { due on the deferral dates }\end{array}$ & $\begin{array}{l}\text { Principal and accrued } \\
\text { interest. Creditors will have } \\
\text { the choice to decide on a } \\
\text { bilateral basis whether or not } \\
\text { to participate in a debt relief. }\end{array}$ \\
\hline Deferral Dates & $\begin{array}{l}\text { - Up to } 6 \text { months or one } \\
\text { payment date (if CCRIF SPC } \\
\text { payout is greater than US } \$ 15 \\
\text { million and less than US } \$ 30 \\
\text { million) } \\
\text { - Up to } 12 \text { months or two } \\
\text { payment dates (if CCRIF } \\
\text { SPC payout is greater than } \\
\text { US } \$ 30 \text { million) }\end{array}$ & $\begin{array}{l}12 \text { months (two payment } \\
\text { dates) }\end{array}$ & Unspecified \\
\hline Repayments Terms & $\begin{array}{l}\text { - Principal deferred and } \\
\text { accrued interest deferred and } \\
\text { capitalized } \\
\text { - Both repayable in equal } \\
\text { semi-annual installments } \\
\text { over the remaining term of } \\
\text { the loan }\end{array}$ & $\begin{array}{l}\text { - Principal deferred and } \\
\text { accrued interest deferred and } \\
\text { capitalized } \\
\text { - Both repayable in equal } \\
\text { semi-annual installments } \\
\text { over the remaining term of } \\
\text { the loan }\end{array}$ & Unspecified \\
\hline Conditions & $\begin{array}{l}\text { Policy payout by CCRIF SPC } \\
\text { and submission of the deferral } \\
\text { claim }\end{array}$ & $\begin{array}{l}\text { Policy payout by CCRIF SPC } \\
\text { and submission of the deferral } \\
\text { claim }\end{array}$ & $\begin{array}{l}\text { Considerable damage and } \\
\text { formal request }\end{array}$ \\
\hline $\begin{array}{l}\text { Maximum Numbers } \\
\text { of Triggers }\end{array}$ & Three & Three & Not stated \\
\hline Reporting & $\begin{array}{l}\text { Progress reports on post- } \\
\text { event relief, recover and } \\
\text { reconstruction programs }\end{array}$ & $\begin{array}{l}\text { Progress reports on post- } \\
\text { event relief, recover and } \\
\text { reconstruction programs }\end{array}$ & Not stated \\
\hline
\end{tabular}

Sources: Grenadian authorities and Paris Club data. 


\section{APPENDIX 2.}

\section{Grenada's Redemption Profile Pre- and Post-Debt Restructuring}

\section{Figure A1}

Grenada's Redemption Profile Pre- and Post-Debt Restructuring

(in millions of East Caribbean dollars)

Pre-Debt Restructuring

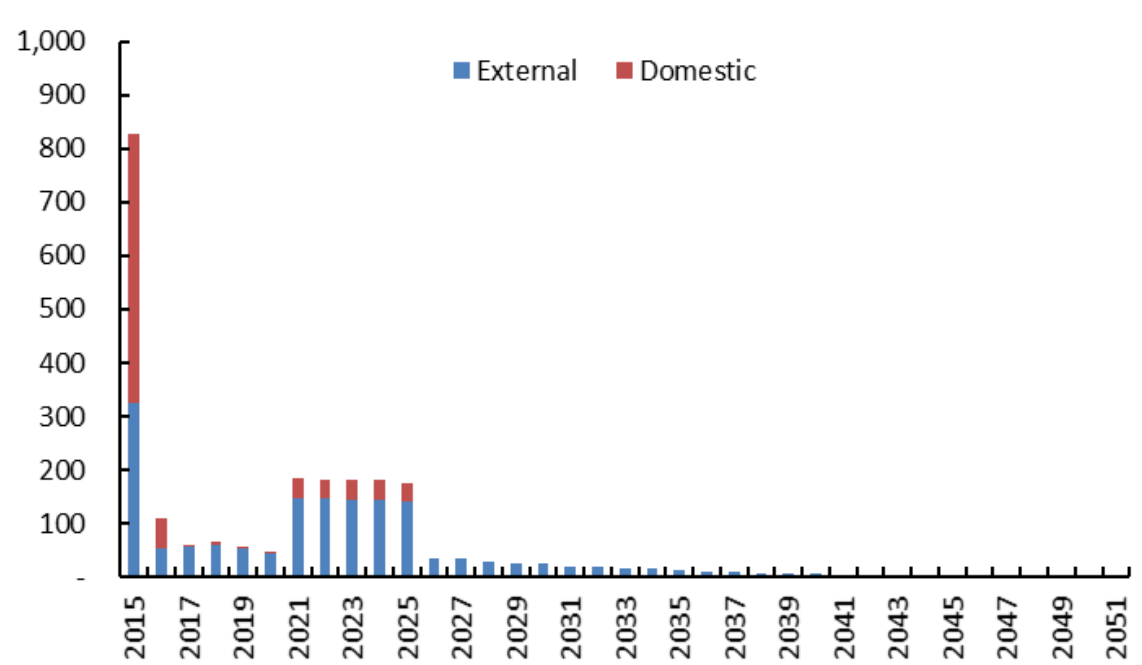

Post-Debt Restructuring

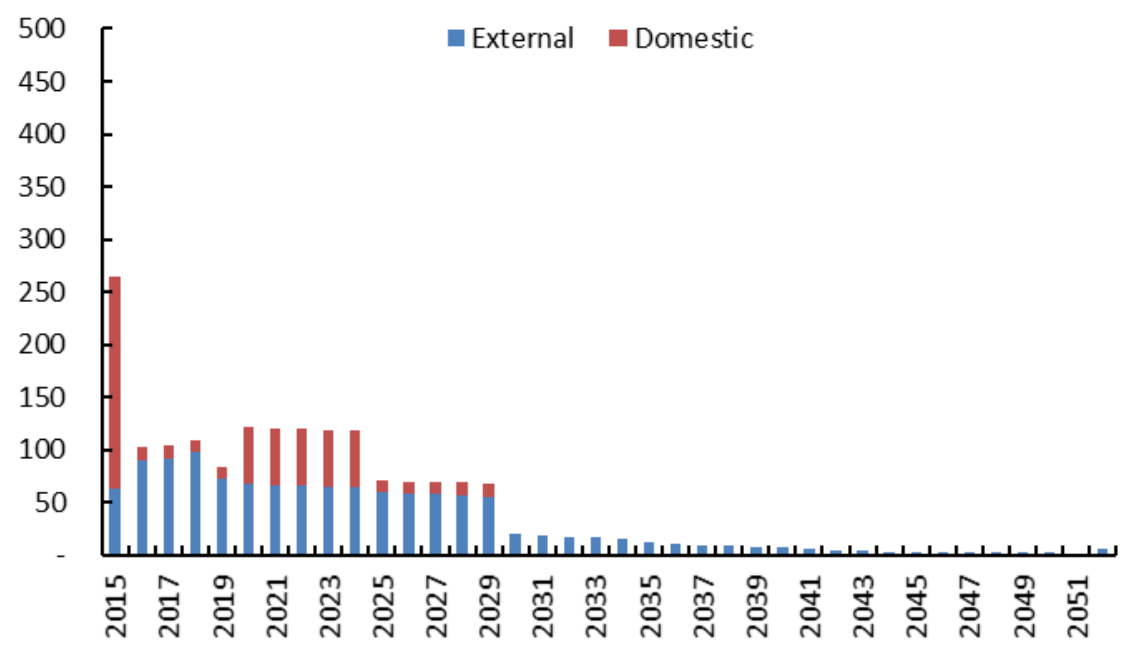

Sources: Authors' calculations based on Grenadian statistics. 


\section{APPENDIX 3.}

\section{Was Grenada's 2004-06 Debt Restructuring "Too Little, Too Late"?}

Was Grenada's 2004-06 debt restructuring in fact "too little, too late"? Could it have been designed differently to prevent the second restructuring a decade later? ${ }^{59}$

First, we assess the NPV of the haircut that had to be indifferent between the two restructurings and one (hypothetical) deeper restructuring in 2004-06. By examining this counterfactual, we can determine the loss experienced by a bondholder who held the original debt in 2005 and subsequently underwent the two restructurings. To this end, the cash flow of the original debt before the 2004-06 debt restructuring and the cash flow of the combined 2004-06 and 2013-15 debt restructurings are compared. In the illustrative analysis below, only the debt restructurings of the commercial debt are compared. The panel charts below shows the cash flows of (1) the original debt that was restructured in November 2005 (in green); (2) the 2004-06 debt restructuring representing the 2025 bonds (in blue); and (3) the 2013-15 debt restructuring representing the 2030 bonds (in red). The actual cash payments made in (2), explained below, and the new cash flows in (3) will be referred to as the combined debt restructuring and represent the cash flows of a hypothetical bondholder who underwent both debt restructurings (in purple). ${ }^{60}$

Original, Nov. 2005 Exchange, and Nov. 2015 Exchange

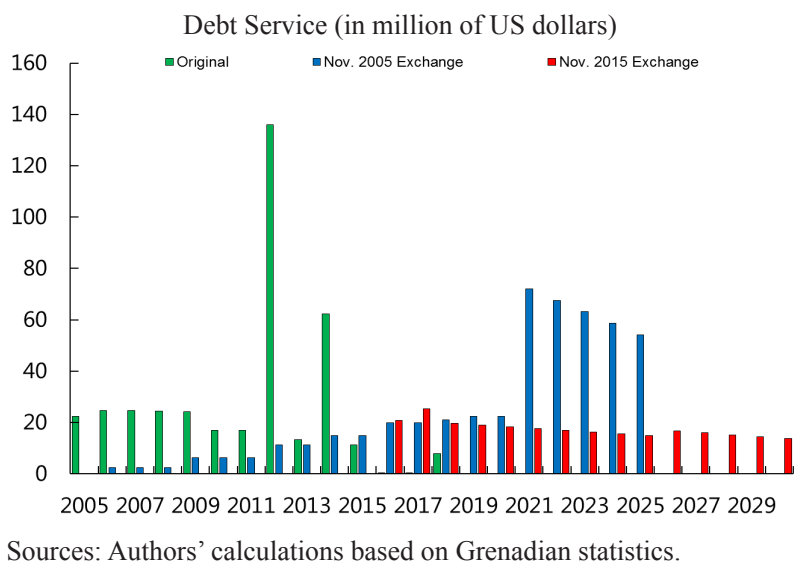

\section{Original and Combined Nov. 2005 and Nov. 2015 Exchanges}

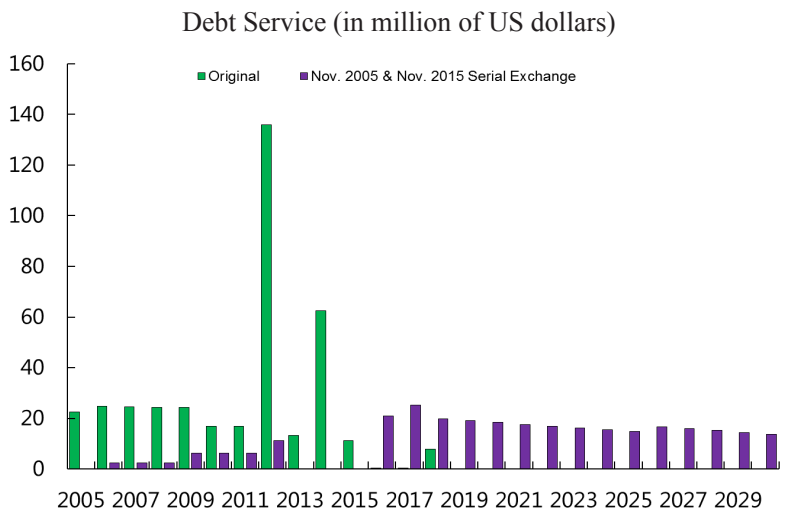

Comparing the original cash flow of the pre-2004-06 debt restructuring (in green) with the cash flow of the combined debt restructuring (in purple) allowed us to assess the restructuring terms needed in November 2005 to having an equivalent outcome to the two debt restructurings. We compared the present values of the two cash flows as of November 2005. Using the exit yield at the time of the 2004-06 debt restructuring (8.9 percent), the NPV haircut for the original 2004-06 debt restructuring was 35 percent. For the combined debt restructuring, using the same exit yield, the NPV haircut was 51 percent. In other words, to have possibly avoided the second restructuring (or to equalize the combined NPV haircuts), a NPV haircut of 51 percent with a principal reduction would have been needed in November 2005, instead of the 35 percent with only maturity extension and early coupon relief that creditors gave to Grenada at the time. ${ }^{61} \mathrm{In}$ fact, a principal reduction similar to that of the 2013-15 restructuring may have required less NPV reduction than the combined NPV haircut. This analysis illustrates that the first restructuring may have been "too little, too late," necessitating the second debt restructuring.

\footnotetext{
59 See IMF (2013) for a discussion on "too little, too late." See also the analysis comparing the two debt restructurings in this appendix, where it is shown that an early reduction of the principal could lead to a sustained and robust reduction in the debt trajectory.

60 To construct the combined debt restructuring cash flow, only the actual payments for (2) are taken, as only coupon payments were made between 2006 and September 2012 (before the announcement of the default in March 2013), based on the terms of the 2005 debt restructuring in a step-up fashion, with amortization scheduled not to start until 2021. Payments (interest plus principal on an amortizing schedule) on the new 2030 bonds began in May 2016.

61 Using the exit yield prevailing at the time of the 2015 restructuring (13.9 percent), the NPV reduction of the combined debt restructuring was 69 percent.
} 


\section{APPENDIX 4.}

\section{Comparison of Debt Restructurings in the Caribbean}

Several Caribbean countries have experienced sovereign debt restructurings over the past 10 years. This Appendix reviews debt restructuring episodes in the region: Antigua and Barbuda in 2008-12, Belize in 2006-07 and 2012-13, Dominica in 2004, Dominican Republic in 2004-05, Jamaica in 2010 and 2013, and St. Kitts and Nevis in 2012-13 (see Table A1 for details of debt restructurings). We then compare Grenada's two debt restructurings in 2004-06 and 2013-15 with the general restructuring pattern in the region.

Fiscal policy slippages and output losses related to external shocks, including hurricanes, are two dominant drivers of debt accumulation to "unsustainable levels." 62 The lack of effective monetary policy under a fixed exchange rate regime in most of these countries has frequently led to a countercyclical fiscal policy response that led to a rapid accumulation of debt. Grenada's two debt restructurings are a representative case in the region.

Most debt restructurings in the Caribbean are implemented in a preemptive, collaborative manner and are generally completed over a short duration. Three restructurings went against the trend, as negotiations started after missed debt service payments (default): Antigua and Barbuda in 2008-12, Dominican Republic's restructuring on external bank loans in 2004-05, and Grenada's 2013-15 restructuring. Similarly, Antigua and Barbuda's 2008-12 and Grenada's 2013-15 restructurings involved protracted negotiations that lasted over more than 2.5 years. This was because of litigation over disputed claims in the US court system (Antigua and Barbuda) and of the need for a deep principal reduction to restore debt sustainability (Grenada).

The majority of countries, with the exception of Belize, Dominica, and Jamaica, have had both private and official sector debt restructurings in sequence, alongside an IMF-supported program. Only the episodes in Belize in 2006-07 and 2012-13, Dominica in 2003-04, and Jamaica in 2010 and 2013 were stand-alone private debt restructurings without official external debt restructurings. Against the pattern in the region, the restructurings in Belize in 2006-07 and 2012-13 and in Grenada in 2004-06 were completed outside an IMF-supported program.

A third of these restructurings included sizable face-value reductions (resulting in higher NPV haircuts), while others do not. Antigua and Barbuda's restructuring in 2008-12, Dominica's in 2003-04, Grenada's in 2013-15, and St. Kitts and Nevis's in 2011-12 included face-value reductions resulting in NPV haircuts above 50 percent. In contrast, the remaining cases were associated with treatments of maturity extension and coupon rate reduction.

Debt sustainability concerns remained unresolved for most debt restructurings (Asonuma et al. 2017c), while most countries had difficulty regaining market access. Despite settlements with private external creditors, and subsequently with official debt restructurings, public debt has remained elevated even after the completion of exchange in most cases. Associated with this, countries have remained excluded from the international capital market for protracted periods. In this respect, the Dominican Republic's restructuring in 2004-05 was exceptional in that the country regained market access after only five to ten months.

Grenada's 2013-15 restructuring incorporated some original, innovative features. These innovations included: (1) a two-step nominal haircut in the commercial bond deal, with half of the 50 percent haircut executed at the time of the exchange (2015) and the remainder contingent on successful completion of the IMF-supported program in 2017. The first nominal haircut can be reversed in the event Grenada does not complete the IMF-supported program; (2) a hurricane clause, introduced first in the Ex-Im Bank restructuring and also in the commercial bond deal and Paris Club agreements, to provide the debtor with temporary debt service relief in the event of qualifying natural disasters; and (3) to make the deal more attractive to promote participation, the commercial bond agreement included a clause to "claw back" some of the proceeds (up to a certain threshold) from the CBI program - an upside potential for NPV recovery. The third innovation was first introduced in the St. Kitts and Nevis restructuring, while Grenada was the first to introduce the first and second tools in its 2013-15 deal.

62 IMF (2013) also emphasizes an additional factor, that is, the fear of contagion may generate delay in the authorities' policy action to debt sustainability. 


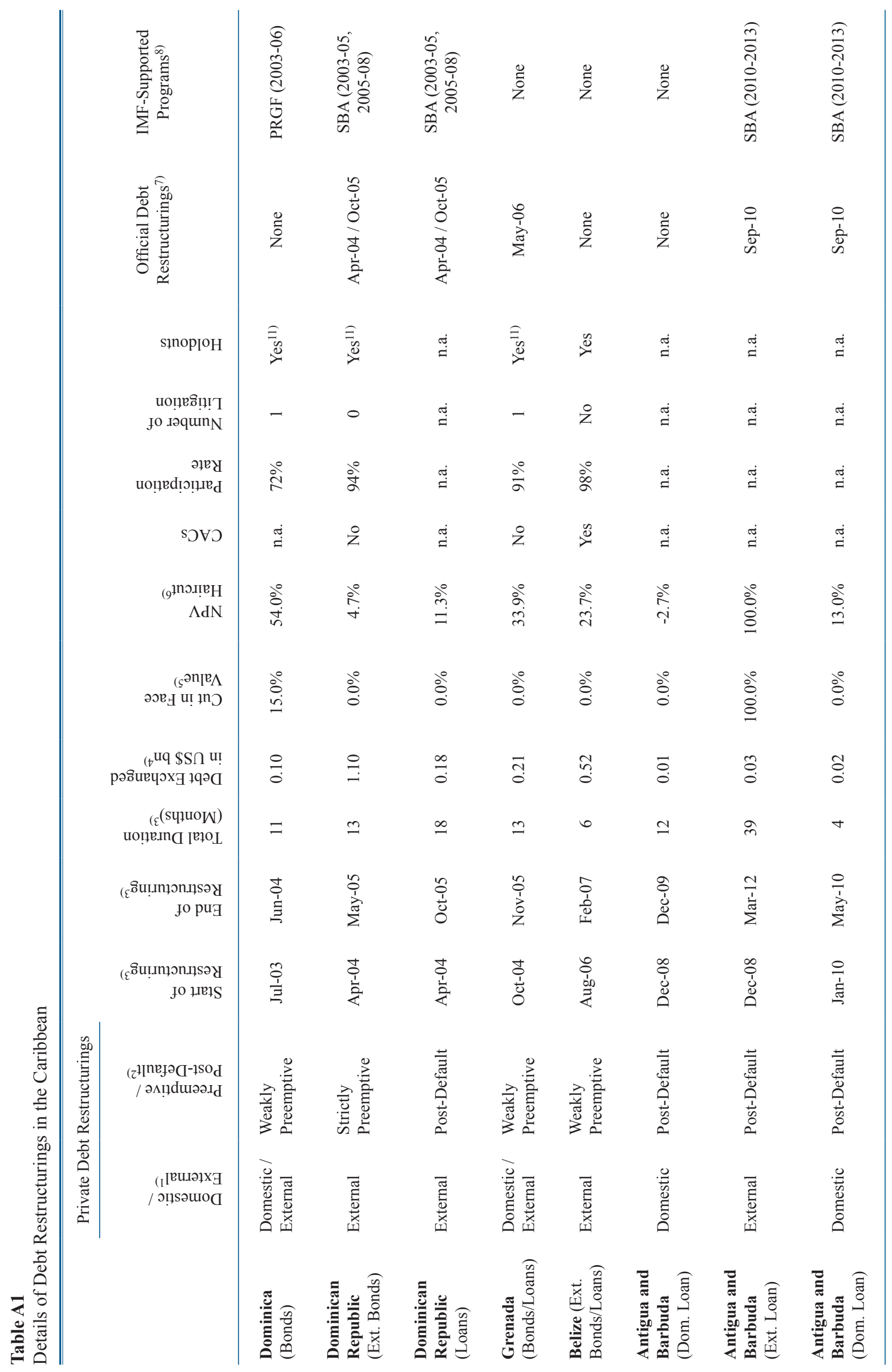




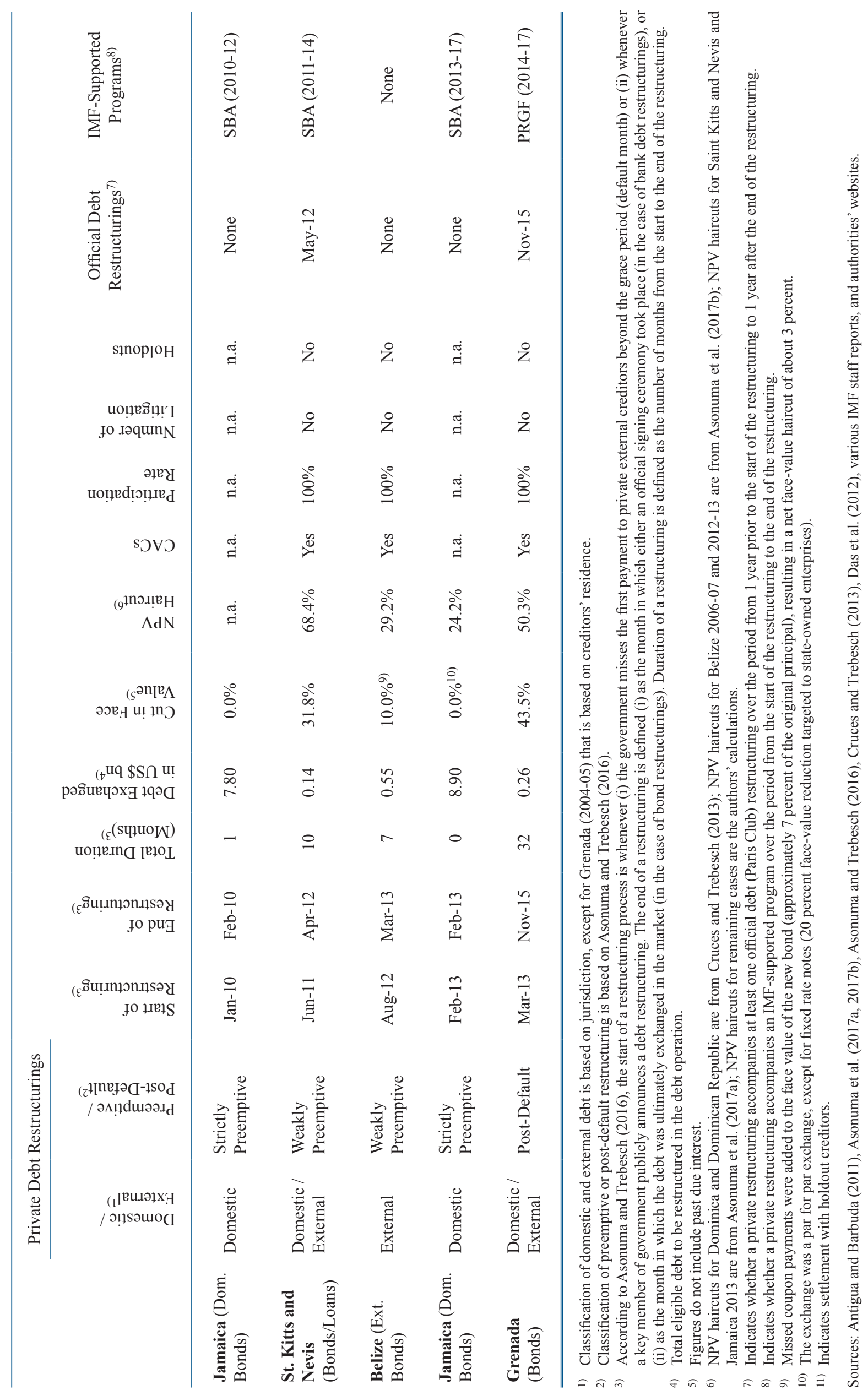

